\title{
Supporting Information for: Methionine adenosyltransferase engineering to enable bioorthogonal platforms for AdoMet-utilizing enzymes
}

Tyler D. Huber ${ }^{1,2}$, Jonathan Clinger ${ }^{3}$, Yang Liu ${ }^{1,2}$, Weijun $\mathrm{Xu}^{3}$, Mitchell D. Miller ${ }^{3}$, George N. Phillips, Jr. ${ }^{3,4}$, and Jon S. Thorson ${ }^{1,2}$

${ }^{1}$ Department of Pharmaceutical Sciences, College of Pharmacy, University of Kentucky, 789 South Limestone Street, Lexington, KY 40536-0596, USA; ${ }^{2}$ Center for Pharmaceutical Research and Innovation (CPRI), College of Pharmacy, University of Kentucky, 789 South Limestone Street, Lexington, KY 405360596, USA; ${ }^{3}$ Department of Biosciences, Rice University, 6100 Main Street, Houston, TX 77251-1892, USA; ${ }^{4}$ Department of Chemistry, Rice University, Space Science 201, Houston, TX 77251-1892, USA

\section{Table of Contents}

1. General materials and methods

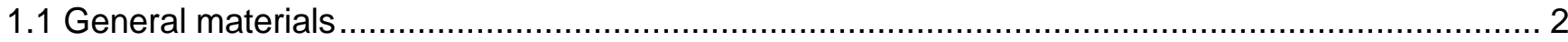

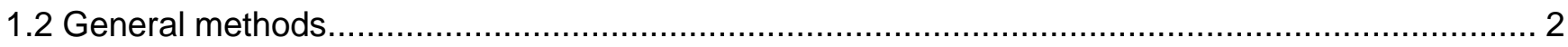

2. General procedure for the synthesis of metOMe, metOEt, metOPr, and metOBu ........................... 2

3. General procedure for the synthesis of metolMe, metolEt, and metolPr .................................... 4

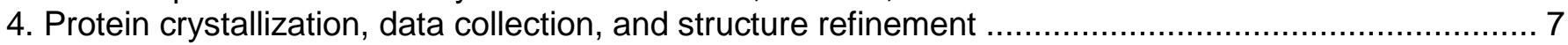

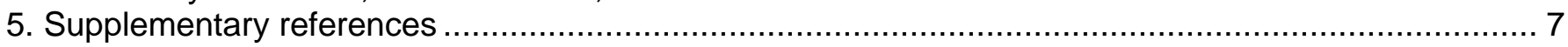

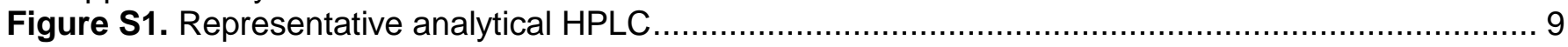

Figure S2. Determination of kinetic parameters for mutant and wt-hMAT2A-catalyzed reactions .......... 10

Figure S3. hMAT2A-K289L electron density map ............................................................. 11

Figure S4. Combinatorial plate-based screen of targeted hMAT2A mutants with L-Met analogues ....... 12

Table S1. Summary of crystal parameters, data collection, and refinement statistics ........................ 13

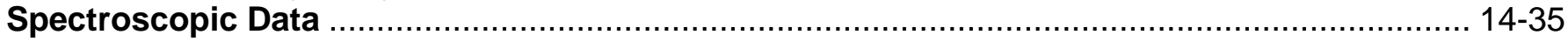




\section{General materials and methods.}

1.1 General materials. Unless otherwise stated, all general chemicals and reagents (including methionine analogues 2, 3, and 13 - 15) were purchased from Sigma-Aldrich (St. Louis, MO) and were reagent grade or better. Metamine, or (2S)-4-(methylsulfanyl)butane-1,2-diamine, was purchased from Enamine Ltd. (Kyiv, Ukraine). Metamide, or (S)-2-amino-4-(methylthio)butanamide, was synthesized as previously described. $^{\mathrm{S} 1} \mathrm{~S}$-adenosyl-L-methionine (AdoMet) was purchased as a $32 \mathrm{mM}$ solution in $10 \% \mathrm{EtOH} / 5 \mathrm{mM}$ $\mathrm{H}_{2} \mathrm{SO}_{4}$ from New England Biolabs (Ipswich, MA). E. coli BL21(DE3) competent cells were purchased from New England Biolabs (Ipswich, MA). The pET28a E. coli expression vector was purchased from Novagen (Madison, WI). Primers were purchased from Integrated DNA Technologies (Coralville, IA). QuikChange II site-directed mutagenesis kits were purchased from Agilent Technologies (Santa Clara, CA). PD-10 columns and Ni-NTA superflow columns were purchased from GE Healthcare (Piscataway, NJ). Crystal screen kits were purchased from Hampton Research (Aliso Viejo, CA), Molecular Dimensions (Altamonte Springs, FL), Rigaku (Seattle, WA) and Microlytic (Burlington, MA).

1.2 General methods. X-ray data were collected at beamline 21-ID-F (LS-CAT) in the Advanced Photon Source at Argonne National Laboratory (Chicago, IL). NMR spectra were obtained on a Varian Unity Inova $400 \mathrm{MHz}$ instrument (Palo Alto, CA) at the University of Kentucky College of Pharmacy NMR facility using $\mathrm{CDCl}_{3}(\mathrm{D}, 99.96 \%)$ with or without $0.05 \%$ v/v TMS from Cambridge Isotopes (Cambridge Isotope Laboratories, MA). ${ }^{1} \mathrm{H}$ and ${ }^{13} \mathrm{C}$ chemical shifts were referenced to internal solvent resonances. Multiplicities are indicated by s (singlet), $d$ (doublet), dd (doublet of doublets), t (triplet), q (quartet), quin (quintet), $\mathrm{m}$ (multiplet), and br (broad). Chemical shifts are reported in parts per million (ppm) and coupling constants $J$ are given in $\mathrm{Hz}$. Routine ${ }^{13} \mathrm{C}$ NMR spectra were fully decoupled by broad-broad WALTZ decoupling. All NMR spectra were recorded at ambient temperature.

Normal-phase flash chromatography was performed on 40-63 $\mu \mathrm{m}, 60 \AA$ silica gel (Silicycle, Quebec). Analytical TLC was performed on silica gel glass TLC plates (EMD Chemicals Inc, Gibbstown, NJ). Visualization was accomplished with UV light $(254 \mathrm{~nm})$ followed by staining with dilute $\mathrm{H}_{2} \mathrm{SO}_{4}(5 \%$ in EtOH) solution, $\mathrm{KMnO}_{4}$ solution ( $1.5 \mathrm{~g}$ of $\mathrm{KMnO}_{4}, 10 \mathrm{~g} \mathrm{~K}_{2} \mathrm{CO}_{3}$, and $1.25 \mathrm{~mL} 10 \% \mathrm{NaOH}$ in $200 \mathrm{~mL}$ water) and heating, or 10\% ninhydrin in EtOH and heating. HPLC was accomplished using an Agilent 1260 system equipped with a DAD detector. HPLC Method: To monitor enzyme reactions, analytical reversephase (RP) HPLC was conducted with a Luna $\mathrm{C}_{18}(5 \mu \mathrm{m}, 4.6 \mathrm{~mm} \times 250 \mathrm{~mm}$; Phenomenex, Torrance, California, USA) column [gradient of $1 \%$ B to $20 \%$ B over $5 \mathrm{~min}, 20 \%$ B to $55 \%$ B over $15 \mathrm{~min}, 55 \%$ B to $100 \%$ B over $1 \mathrm{~min}, 100 \% \mathrm{~B}$ for $5 \mathrm{~min}, 100 \% \mathrm{~B}$ to $1 \% \mathrm{~B}$ over $1 \mathrm{~min}, 1 \% \mathrm{~B}$ for $8 \mathrm{~min}\left(\mathrm{~A}=\mathrm{ddH}_{2} \mathrm{O}\right.$ with $0.1 \%$ formic acid; $B=$ acetonitrile) flow rate $=0.4 \mathrm{~mL} \mathrm{~min}^{-1} ; \mathrm{A}_{254}, \mathrm{~A}_{260}$.

\section{General procedure for the synthesis of metOMe, metOEt, metOPr, and metOBu}

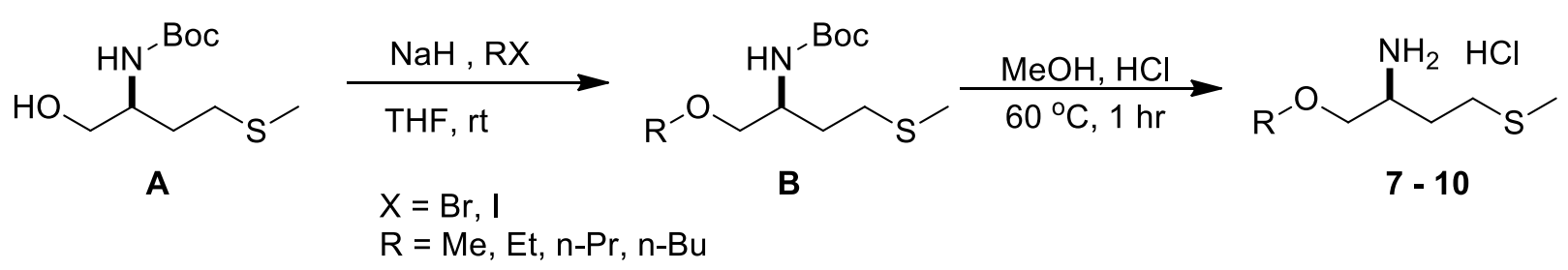

Rxn 1: $\mathrm{NaH}$ (26 mg, $0.65 \mathrm{mmol}$ ) was added to a solution of compound $\mathbf{A}$ ( 0.7 equivalents) in $4.3 \mathrm{~mL}$ dry THF at $0{ }^{\circ} \mathrm{C}$. The mixture was stirred for $10 \mathrm{~min}$, alkyl halide (1.3 equivalents) was added, and the reaction continued for an additional $1.5 \mathrm{hr}$ with stirring (monitored by TLC and LC-MS). The organics were removed under vacuum and the residue was purified by normal-phase column chromatography ( $n$-hexane:EtOAc, $20: 1 \sim 8: 1)$ to give the desired product $\mathbf{B}$. 
Rxn 2: Compound B $(0.2 \mathrm{mmol})$ was dissolved in $1.5 \mathrm{~mL} \mathrm{MeOH} .0 .5 \mathrm{~mL}$ concentrated $\mathrm{HCl}$ was added and the mixture was refluxed at $60^{\circ} \mathrm{C}$ for $1.5 \mathrm{hr}$ (monitored by TLC, stained by iodine). Upon completion, solvent was removed under vacuum to give the $\mathrm{HCl}$ salt of product $\mathbf{7 , 8 , 9}$, or 10 .<smiles>COCC(N)CCSC</smiles>

(S)-1-Methoxy-4-(methylthio)butan-2-amine (metOMe, 7). Methyl iodide (122 $\mathrm{mg}, 0.86 \mathrm{mmol}$ ) was used to obtain the product as a white solid (66 mg, 2 steps, $81 \%$ yield). ${ }^{1} \mathrm{H}$ NMR $\left(400 \mathrm{MHz} \mathrm{CDCl}_{3}\right) \delta: 8.49$ (s, $2 \mathrm{H})$, 3.53-3.69 (m, 3H), $3.42(\mathrm{~s}, 3 \mathrm{H}), 2.62-2.75(\mathrm{~m}, 2 \mathrm{H})$ 2.14-2.26 (m, 1H), $2.12(\mathrm{~s}, 3 \mathrm{H}), 1.92-2.05(\mathrm{~m}, 1 \mathrm{H})$. ${ }^{13} \mathrm{C}$ NMR $\left(100 \mathrm{MHz} \mathrm{CDCl}_{3}\right) \delta: 71.2,59.2,50.6,29.8,28.5,15.2$. HRMS $[\mathrm{M}+\mathrm{H}]{ }^{+}$calculated for $\mathrm{C}_{6} \mathrm{H}_{16} \mathrm{NOS}$ 150.0947, found 150.0946 .<smiles>CCOCC(N)CCSC</smiles>

(S)-1-Ethoxy-4-(methylthio)butan-2-amine (metOEt, 8). Ethyl iodide (135 $\mathrm{mg}, 0.86 \mathrm{mmol}$ ) was used to obtain the product as a white solid (38 mg, 2 steps, $55 \%$ yield). ${ }^{1} \mathrm{H} \mathrm{NMR}\left(400 \mathrm{MHz}, \mathrm{CDCl}_{3}\right) \delta: 8.47(\mathrm{~s}, 2 \mathrm{H})$, 3.49-3.73 (m, 5H), 2.60-2.75 (m, 2H) 2.14-2.25 (m, 1H), $2.12(\mathrm{~s}, 3 \mathrm{H}), 1.94-2.05(\mathrm{~m}, 1 \mathrm{H}), 1.24(\mathrm{t}, \mathrm{J}=7.0 \mathrm{~Hz}$ $3 \mathrm{H}) .{ }^{13} \mathrm{C}$ NMR $\left(100 \mathrm{MHz}, \mathrm{CDCl}_{3}\right) \delta: 69.0,67.0,50.8,29.8,28.5,15.1,15.0 . \mathrm{HRMS}[\mathrm{M}+\mathrm{H}]^{+}$calculated for $\mathrm{C}_{7} \mathrm{H}_{18} \mathrm{NOS}$ 164.1104, found 164.1101.<smiles>CCCOCC(N)CCSC</smiles>

(S)-4-(Methylthio)-1-propoxybutan-2-amine (metOPr, 9). 1-Bromopropane (105 mg, $0.86 \mathrm{mmol}$ ) was used to obtain the product as a light yellow solid $\left(115 \mathrm{mg}, 2\right.$ steps, $49 \%$ yield). ${ }^{1} \mathrm{H}$ NMR $\left(400 \mathrm{MHz} \mathrm{CDCl}_{3}\right)$ ס: $8.48(\mathrm{~s}, 2 \mathrm{H}), 3.52-3.71(\mathrm{~m}, 3 \mathrm{H}), 3.40-3.51(\mathrm{~m}, 2 \mathrm{H}), 2.61-2.76(\mathrm{~m}, 2 \mathrm{H}) 2.14-2.25(\mathrm{~m}, 1 \mathrm{H}), 2.12(\mathrm{~s}, 3 \mathrm{H})$, 1.94-2.05 (m, 1H), 1.57-1.68 (m, 2H), $0.92(\mathrm{t}, J=7.5 \mathrm{~Hz} 3 \mathrm{H}) .{ }^{13} \mathrm{C}$ NMR $\left(100 \mathrm{MHz}, \mathrm{CDCl}_{3}\right)$ ס: $73.3,69.2$, 50.7, 29.8, 28.5, 22.6, 15.1, 10.5. HRMS $[\mathrm{M}+\mathrm{H}]^{+}$calculated for $\mathrm{C}_{8} \mathrm{H}_{20} \mathrm{NOS}$ 178.1260, found 178.1255.<smiles>CCCCOCC(N)CCSC</smiles>

(S)-1-Butoxy-4-(methylthio)butan-2-amine (metOBu, 10). $n$-Butyl bromide (118 $\mathrm{mg}, 0.86 \mathrm{mmol}$ ) was used to obtain the product as a light yellow solid $\left(251 \mathrm{mg}, 2\right.$ steps, $55 \%$ yield). ${ }^{1} \mathrm{H}$ NMR $\left(400 \mathrm{MHz}, \mathrm{CDCl}_{3}\right)$ ס: $8.45(\mathrm{~s}, 2 \mathrm{H}), 3.55-3.71(\mathrm{~m}, 3 \mathrm{H}), 3.46-3.53(\mathrm{~m}, 2 \mathrm{H}), 2.62-2.77(\mathrm{~m}, 2 \mathrm{H})$ 2.15-2.25 $(\mathrm{m}, 1 \mathrm{H}), 2.13(\mathrm{~s}, 3 \mathrm{H})$, 1.94-2.07 $(\mathrm{m}, 1 \mathrm{H}), 1.54-1.64(\mathrm{~m}, 2 \mathrm{H}), 1.31-1.42(\mathrm{~m}, 2 \mathrm{H}), 0.92(\mathrm{t}, J=7.5 \mathrm{~Hz} 3 \mathrm{H}) .{ }^{13} \mathrm{C} \mathrm{NMR}(100 \mathrm{MHz}$, $\left.\mathrm{CDCl}_{3}\right) \delta: 71.5,69.2,50.8,31.4,29.8,28.5,19.2,15.1,13.9$. HRMS $[\mathrm{M}+\mathrm{H}]^{+}$calculated for $\mathrm{C}_{9} \mathrm{H}_{22} \mathrm{NOS}$ 192.1417, found 192.1416 . 


\section{General procedure for the synthesis of metolMe, metolEt, and metolPr}
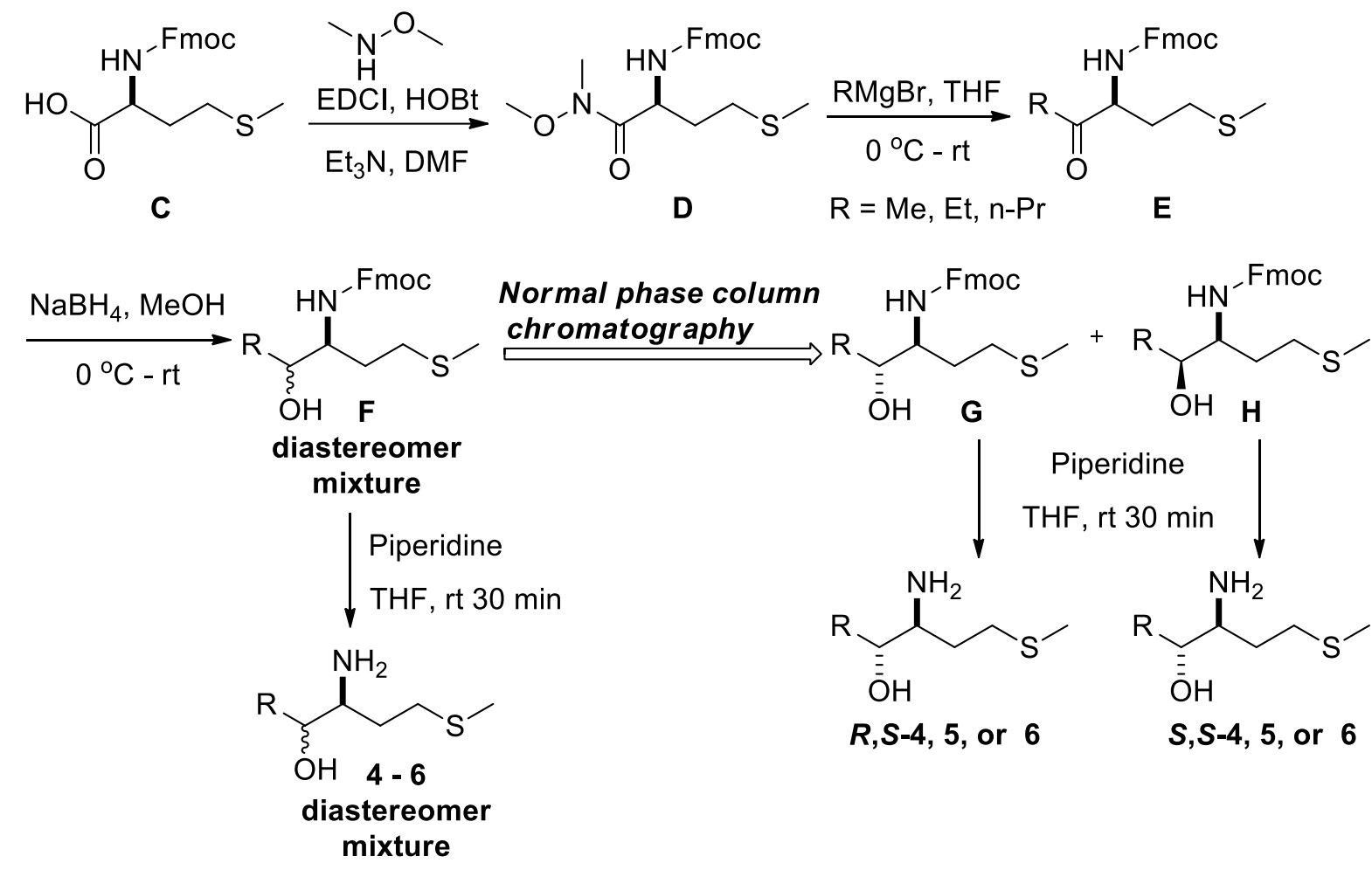

Rxn 1: N,O-dimethylhydroxylamine hydrochloride (1.25 g, $12.5 \mathrm{mmol}), \mathrm{HOBt}(1.7 \mathrm{~g}, 12.5 \mathrm{mmol})$ and EDCl $(2.4 \mathrm{~g}, 12.5 \mathrm{mmol})$ were added to a solution of compound $\mathbf{C}(3.7 \mathrm{~g}, 10 \mathrm{mmol})$ in $25 \mathrm{~mL}$ dry DMF. The mixture was stirred for $1 \mathrm{hr}$, then $\mathrm{Et}_{3} \mathrm{~N}(1.7 \mathrm{~mL}, 12.5 \mathrm{mmol})$ was added and the reaction stirred for an additional $5 \mathrm{hr}$ (monitored by TLC and LC-MS). Upon completion, the reaction was diluted with $100 \mathrm{~mL}$ $\mathrm{H}_{2} \mathrm{O}$ and extracted with EtOAc $(50 \mathrm{~mL} \times 2)$, washed with water $(100 \mathrm{~mL} \times 2)$, brine $(50 \mathrm{~mL} \times 1)$ and then dried over $\mathrm{Na}_{2} \mathrm{SO}_{4}$. The mixture was filtered, organic solvent was removed under vacuum, and the crude mixture purified by normal-phase column chromatography ( $n$-hexane:EtOAc, 4:1 1:1) to give the desired product $\mathbf{D}$ as a white solid, $75 \%$ yield.

Rxn 2: Alkyl magnesium halide ( $3 \mathrm{M}$ in THF, $3.0 \mathrm{mmol}, 1 \mathrm{~mL}$ total volume) was added dropwise to a solution of $\mathbf{D}(1.0 \mathrm{~g}, 2.4 \mathrm{mmol})$ in $20 \mathrm{~mL}$ dry THF at $0{ }^{\circ} \mathrm{C}$ and the mixture was stirred at room temperature for $6 \mathrm{hr}$ (monitored by TLC and LC-MS). Saturated $\mathrm{NH}_{4} \mathrm{Cl}$ solution $(50 \mathrm{~mL}$ ) was added to quench the reaction and the reaction was extracted by EtOAc $(50 \mathrm{~mL} \times 2)$, washed with water $(50 \mathrm{~mL} \times 2)$, brine $(50$ $\mathrm{mL} \times 1$ ) and dried over $\mathrm{Na}_{2} \mathrm{SO}_{4}$. The organic solvent was removed under vacuum and the residue was purified by normal-phase column chromatography ( $n$-hexane:EtOAc, 8:1 2:1) to give the desired product $\mathbf{E}(\mathrm{R}=\mathrm{Me}, 69 \%$ yield; $\mathrm{R}=\mathrm{Et}, 60 \%$ yield; $\mathrm{R}=n-\operatorname{Pr}, 51 \%$ yield $)$.

Rxn 3: $\mathrm{NaBH}_{4}(74 \mathrm{mg}, 2.0 \mathrm{mmol})$ was added to a solution of $\mathbf{E}(1.0 \mathrm{mmol})$ in $5 \mathrm{~mL}$ of $\mathrm{MeOH}$ at $0{ }^{\circ} \mathrm{C}$ and the mixture was stirred at room temperature for $8 \mathrm{hr}$ (monitored by TLC and LC-MS). The reaction was quenched with the addition of $30 \mathrm{~mL} \mathrm{H} \mathrm{H}_{2} \mathrm{O}$ and the mixture was extracted by EtOAc $(30 \mathrm{~mL} \times 2)$, washed with water $(30 \mathrm{~mL} \times 2)$, brine $(30 \mathrm{~mL} \times 1)$ and then dried over $\mathrm{Na}_{2} \mathrm{SO}_{4}$. The organics were removed under vacuum and the residue was purified by normal-phase column chromatography ( $n$-hexane:EtOAc, 8:1 $2: 1)$ to give the desired product $F(R=M e, 75 \%$ yield; $R=E t, 66 \%$ yield; $R=n-\operatorname{Pr}, 71 \%$ yield $)$. 
Rxn 4: Piperidine (1 $\mathrm{mL}, 12.5 \mathrm{mmol})$ was added to a solution of $\mathbf{F}(0.26 \mathrm{mmol})$ in $4 \mathrm{~mL}$ THF and the mixture was stirred for 30 min (monitored by TLC). Upon completion, solvent was removed under vacuum and the residue was purified by normal-phase column chromatography $\left(\mathrm{CH}_{2} \mathrm{Cl}_{2}: \mathrm{MeOH}, 10: 1 \sim 4: 1\right)$ to give the desired product 4,5 , or 6 .<smiles>CSCCC(NC(C)=O)C(C)O</smiles>

N-Fmoc-4

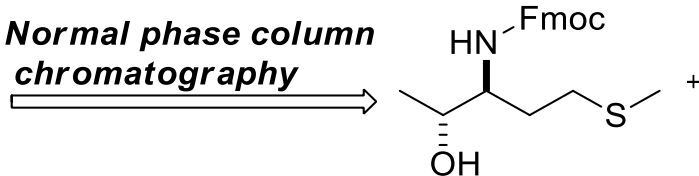

$N-F m o c-R, S-4$<smiles>CSCCC(NC(C)=O)C(C)O</smiles>

N-Fmoc-S,S-4

(9H-Fluoren-9-yl)methyl [(3S)-4-hydroxy-1-(methylthio)pentan-3-yl]carbamate ( $N$-Fmoc-4, $N$-Fmoc$\boldsymbol{R}, \boldsymbol{S}-4$, and $\mathbf{N}$-Fmoc-S, S-4). Methyl magnesium bromide (3 M in THF), (1mL, 3mmol) was used to obtain the diastereomeric mixture (N-Fmoc-4) as a white solid (280 mg, 3 steps, $32 \%$ yield), which was resolved by normal-phase column chromatography to obtain $N$-Fmoc-R,S-4 (31 mg, 3 steps, $3.5 \%$ yield) and $N-$ Fmoc-S, S-4 (95 mg, 3 steps, $10.8 \%$ yield). Enantioselectivity was determined by the NMR analysis of $(R)$ and (S) Mosher esters, N-Fmoc-S,S-4-(R)-MTPA and N-Fmoc-S,S-4-(S)-MTPA, obtained from N-Fmoc$S, S-4$ (see below) following standard protocols. ${ }^{\text {S2 }}$<smiles>CSCCC(NC(C)=O)C(C)O</smiles>

(9H-Fluoren-9-yl)methyl [(3S,4R)-4-hydroxy-1-(methylthio)pentan-3-yl]carbamate ( $N$-Fmoc- $R, S-4)$. ${ }^{1} \mathrm{H}$ NMR $\left(400 \mathrm{MHz} \mathrm{CDCl}_{3}\right) \delta: 7.75(\mathrm{~d}, J=7.4 \mathrm{~Hz} 2 \mathrm{H}), 7.58(\mathrm{~d}, J=7.4 \mathrm{~Hz} 2 \mathrm{H}), 7.38(\mathrm{t}, J=7.4 \mathrm{~Hz} 2 \mathrm{H}), 7.30$ $(\mathrm{t}, J=7.4 \mathrm{~Hz} 2 \mathrm{H}), 4.98(\mathrm{~d}, J=9.4 \mathrm{~Hz} 1 \mathrm{H}), 4.44(\mathrm{~d}, J=6.7 \mathrm{~Hz} 2 \mathrm{H}), 4.20(\mathrm{t}, J=6.7 \mathrm{~Hz} 1 \mathrm{H}), 3.80-3.88(\mathrm{~m}$, $1 \mathrm{H}), 3.55-3.65(\mathrm{~m}, 1 \mathrm{H}), 2.49(\mathrm{~s}, 2 \mathrm{H}), 2.08(\mathrm{~s}, 3 \mathrm{H}), 1.75-1.85(\mathrm{~m}, 2 \mathrm{H}), 1.16(\mathrm{~d}, J=6.3 \mathrm{~Hz} 3 \mathrm{H}) . \mathrm{HRMS}[\mathrm{M}+\mathrm{H}]$ + calculated for $\mathrm{C}_{21} \mathrm{H}_{26} \mathrm{NO}_{3} \mathrm{~S} 372.1628$, found 372.1625 .<smiles>CSCCC(NC(C)=O)C(C)O</smiles>

(9H-Fluoren-9-yl)methyl [(3S,4S)-4-hydroxy-1-(methylthio)pentan-3-yl]carbamate ( $\mathrm{N}$-Fmoc-S, S-4). ${ }^{1} \mathrm{H}$ NMR $\left(400 \mathrm{MHz} \mathrm{CDCl}_{3}\right) \delta: 7.75(\mathrm{~d}, J=7.4 \mathrm{~Hz} 2 \mathrm{H}), 7.58(\mathrm{~d}, J=7.4 \mathrm{~Hz} 2 \mathrm{H}), 7.38(\mathrm{t}, J=7.4 \mathrm{~Hz} 2 \mathrm{H}), 7.30$ $(\mathrm{t}, J=7.4 \mathrm{~Hz} 2 \mathrm{H}), 4.98(\mathrm{~d}, J=9.4 \mathrm{~Hz} 1 \mathrm{H}), 4.44(\mathrm{~d}, J=6.7 \mathrm{~Hz} 2 \mathrm{H}), 4.20(\mathrm{t}, J=6.7 \mathrm{~Hz} 1 \mathrm{H}), 3.80-3.88(\mathrm{~m}$, $1 \mathrm{H}), 3.55-3.65(\mathrm{~m}, 1 \mathrm{H}), 2.49(\mathrm{~s}, 2 \mathrm{H}), 2.08(\mathrm{~s}, 3 \mathrm{H}), 1.75-1.85(\mathrm{~m}, 2 \mathrm{H}), 1.16(\mathrm{~d}, J=6.3 \mathrm{~Hz} 3 \mathrm{H}) . \mathrm{HRMS}[\mathrm{M}+\mathrm{H}]$ + calculated for $\mathrm{C}_{21} \mathrm{H}_{26} \mathrm{NO}_{3} \mathrm{~S} 372.1628$, found 372.1629 .<smiles>COC(C(=O)OC(C)C(CCSC)NC(C)=O)(c1ccccc1)C(F)(F)F</smiles>

$N$-Fmoc-S,S-4-(R)-MTPA

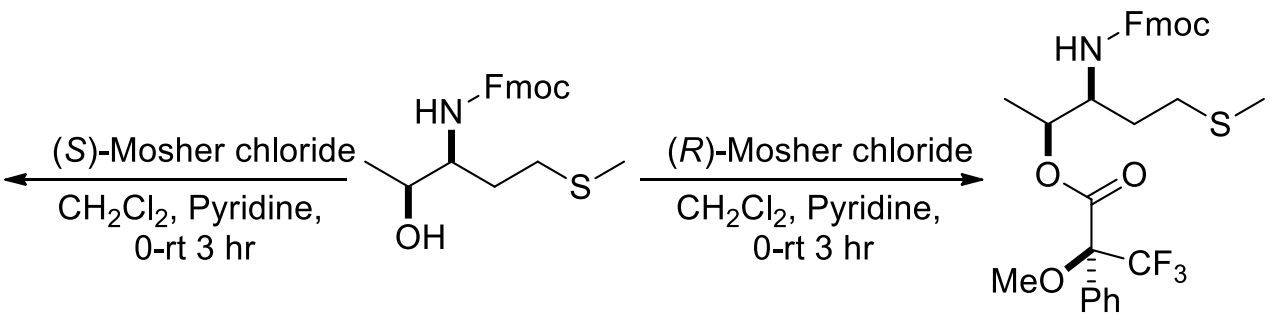

$N-F m o c-S, S-4$
N-Fmoc-S, S-4-(S)-MTPA 
N-Fmoc-S,S-4-(R)-MTPA. The procedures applied to the synthesis of N-Fmoc-S,S-4-(R)-MTPA used $N$ Fmoc-S,S-4 (10 mg, $0.027 \mathrm{mmol})$, pyridine $(10 \mu \mathrm{L}, 0.1 \mathrm{mmol})$ and $(S)-M o s h e r$ chloride $(20 \mu \mathrm{L}, 0.1 \mathrm{mmol})$ to obtain the product as a white solid $\left(12 \mathrm{mg}, 89 \%\right.$ yield). ${ }^{1} \mathrm{H}$ NMR $\left(400 \mathrm{MHz}, \mathrm{CDCl}_{3}\right) \delta: 7.77$ (d, $\mathrm{J}=7.4 \mathrm{~Hz}$ $2 \mathrm{H}), 7.57(\mathrm{~d}, J=7.4 \mathrm{~Hz} 2 \mathrm{H}), 7.28-7.50(\mathrm{~m}, 9 \mathrm{H}), 5.09-5.17(\mathrm{~m}, 1 \mathrm{H}), 4.58(\mathrm{~d}, J=9.4 \mathrm{~Hz} 1 \mathrm{H}), 4.48(\mathrm{~d}, J=$ $6.3 \mathrm{~Hz} 2 \mathrm{H}), 4.20(\mathrm{t}, J=6.3 \mathrm{~Hz} 1 \mathrm{H}), 3.90(\mathrm{t}, J=10.1 \mathrm{~Hz} 1 \mathrm{H}), 3.45(\mathrm{~s}, 3 \mathrm{H}), 2.31-2.52(\mathrm{~m}, 2 \mathrm{H}), 2.04(\mathrm{~s}, 3 \mathrm{H})$, 1.78-1.90 $(\mathrm{m}, 1 \mathrm{H}), 1.45-1.55(\mathrm{~m}, 1 \mathrm{H}), 1.28(\mathrm{~d}, \mathrm{~J}=6.7 \mathrm{~Hz} 3 \mathrm{H}) . \mathrm{HRMS}[\mathrm{M}+\mathrm{H}]^{+}$calculated for $\mathrm{C}_{31} \mathrm{H}_{33} \mathrm{~F}_{3} \mathrm{NO}_{5} \mathrm{~S}$ 588.2026, found 588.2023.

N-Fmoc-S,S-4-(S)-MTPA. The procedures applied to the synthesis of N-Fmoc-S,S-4-(S)-MTPA used NFmoc-S,S-4 (10 mg, $0.027 \mathrm{mmol})$, pyridine $(10 \mu \mathrm{L}, 0.1 \mathrm{mmol})$ and $(R)$-Mosher chloride $(20 \mu \mathrm{L}, 0.1 \mathrm{mmol})$ to obtain the product as a white solid (15 mg, 97\% yield). ${ }^{1} \mathrm{H} \mathrm{NMR}\left(400 \mathrm{MHz}, \mathrm{CDCl}_{3}\right) \delta: 7.77$ (d, $\mathrm{J}=7.5 \mathrm{~Hz}$ $2 \mathrm{H}), 7.57(\mathrm{~d}, J=7.5 \mathrm{~Hz} 2 \mathrm{H}), 7.28-7.50(\mathrm{~m}, 9 \mathrm{H}), 5.12-5.20(\mathrm{~m}, 1 \mathrm{H}), 4.41-4.53(\mathrm{~m}, 3 \mathrm{H}), 4.20(\mathrm{t}, J=6.2 \mathrm{~Hz}$ $1 \mathrm{H}), 3.84(\mathrm{t}, J=10.2 \mathrm{~Hz} 1 \mathrm{H}), 3.54(\mathrm{~s}, 3 \mathrm{H}), 2.25-2.48(\mathrm{~m}, 2 \mathrm{H}), 1.99(\mathrm{~s}, 3 \mathrm{H}), 1.73-1.84(\mathrm{~m}, 1 \mathrm{H}), 1.35-1.45$ $(\mathrm{m}, 1 \mathrm{H}), 1.34(\mathrm{~d}, \mathrm{~J}=6.3 \mathrm{~Hz} 3 \mathrm{H})$. HRMS $[\mathrm{M}+\mathrm{H}]^{+}$calculated for $\mathrm{C}_{31} \mathrm{H}_{33} \mathrm{~F}_{3} \mathrm{NO}_{5} \mathrm{~S} 588.2026$, found 588.2020.<smiles>CSCCC(N)C(C)O</smiles>

(2R,3S)-3-Amino-5-(methylthio)pentan-2-ol $(R, S$-metolMe, $R, S-4)$. The procedures applied to the synthesis of (2R,3S)-3-amino-5-(methylthio)pentan-2-ol used N-Fmoc- $R, S-4$ (10 mg, $0.027 \mathrm{mmol})$ to obtain the product as a colorless oil $\left(6 \mathrm{mg}, 63 \%\right.$ yield). ${ }^{1} \mathrm{H}$ NMR $\left(400 \mathrm{MHz}, \mathrm{CDCl}_{3}\right) \delta: 3.84-3.96(\mathrm{~m}, 1 \mathrm{H})$, 3.20-3.29 (m, 1H), 2.69-2.81 (m, 2H), $2.13(\mathrm{~s}, 3 \mathrm{H}), 1.85-2.05(\mathrm{~m}, 2 \mathrm{H}), 1.33(\mathrm{~d}, \mathrm{~J}=5.8 \mathrm{~Hz} 3 \mathrm{H}) .{ }^{13} \mathrm{C} N M R$

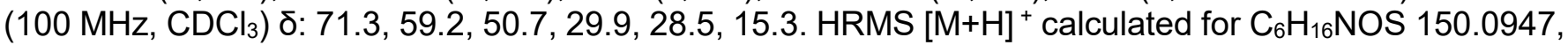
found 150.0943.<smiles>CSCCC(N)C(C)O</smiles>

(2S,3S)-3-Amino-5-(methylthio)pentan-2-ol (S,S-metolMe, S,S-4). The procedures applied to the synthesis of (2S,3S)-3-amino-5-(methylthio)pentan-2-ol used N-Fmoc-S,S-4 (25 mg, $0.067 \mathrm{mmol})$ to obtain the product as a colorless oil $\left(10 \mathrm{mg}, 78 \%\right.$ yield). ${ }^{1} \mathrm{H}$ NMR $\left(400 \mathrm{MHz}, \mathrm{CDCl}_{3}\right) \delta: 4.15-4.25(\mathrm{~m}, 1 \mathrm{H})$, 3.43-3.52 (m, 1H), 2.61-2.81 (m, 2H), $2.13(\mathrm{~s}, 3 \mathrm{H}), 1.96-2.08(\mathrm{~m}, 1 \mathrm{H}), 1.82-1.95(\mathrm{~m}, 1 \mathrm{H}), 1.27(\mathrm{~d}, J=6.7$ $\mathrm{Hz} 3 \mathrm{H}) .{ }^{13} \mathrm{C}$ NMR $\left(100 \mathrm{MHz}, \mathrm{CDCl}_{3}\right) \delta: 71.2,59.3,50.5,29.8,28.5,15.2$. HRMS [M+H] ${ }^{+}$calculated for $\mathrm{C}_{6} \mathrm{H}_{16} \mathrm{NOS} 150.0947$, found 150.0945.<smiles>CCC(O)C(N)CCSC</smiles>

(4S)-4-Amino-6-(methylthio)hexan-3-ol (metolEt, 5). Ethyl magnesium bromide (1 M in THF) (1 mL, 1 $\mathrm{mmol}$ ) was used to obtain the diastereomeric mixture of the product as a colorless oil (27 mg, 4 steps, $18 \%$ yield). ${ }^{1} \mathrm{H}$ NMR $\left(400 \mathrm{MHz}, \mathrm{CDCl}_{3}\right) \delta: 3.37-3.44(\mathrm{~m}, 1 \mathrm{H}), 2.87-2.95(\mathrm{~m}, 1 \mathrm{H}), 2.49-2.71(\mathrm{~m}, 2 \mathrm{H}), 2.10$ $(\mathrm{s}, 3 \mathrm{H}), 1.71-1.81(\mathrm{~m}, 1 \mathrm{H}), 1.49-1.61(\mathrm{~m}, 1 \mathrm{H}), 1.35-1.48(\mathrm{~m}, 2 \mathrm{H}), 0.98(\mathrm{t}, J=7.5 \mathrm{~Hz} 3 \mathrm{H}) .{ }^{13} \mathrm{C}$ NMR $(100$ $\left.\mathrm{MHz}_{2} \mathrm{CDCl}_{3}\right) \delta: 69.2,67.2,51.0,30.0,28.7,15.4,15.2$. HRMS $[\mathrm{M}+\mathrm{H}]^{+}$calculated for $\mathrm{C}_{7} \mathrm{H}_{18} \mathrm{NOS} 164.1104$, found 164.1105 . 


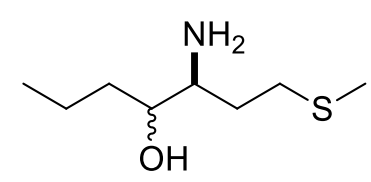

(3S)-3-Amino-1-(methylthio)heptan-4-ol (metolPr, 6). $n$-Propyl magnesium bromide (1 M in THF) (1 mL, $1 \mathrm{mmol}$ ) was used to obtain the diastereomeric mixture of the product as a colorless oil ( $29 \mathrm{mg}, 4 \mathrm{steps}$, $15 \%$ yield). ${ }^{1} \mathrm{H}$ NMR $\left(400 \mathrm{MHz}, \mathrm{CDCl}_{3}\right)$ ס: 3.93-4.00 (m, 1H), 3.33-3.42 (m, 1H), 2.63-2.85 (m, 2H), 2.13 (s, 3H), 1.83-2.05 (m, 2H), 1.45-1.64 (m, 2H), 1.29-1.43 (m, 2H), $0.95(\mathrm{t}, J=7.0 \mathrm{~Hz} 3 \mathrm{H}) .{ }^{13} \mathrm{C}$ NMR $(100$ $\left.\mathrm{MHz}, \mathrm{CDCl}_{3}\right) \delta: 73.1,69.0,50.5,29.6,28.3,22.4,14.9,10.3$. HRMS $[\mathrm{M}+\mathrm{H}]^{+}$calculated for $\mathrm{C}_{8} \mathrm{H}_{20} \mathrm{NOS}$ 178.1260, found 178.1258 .

\section{Protein crystallization, data collection, and structure refinement.}

Large scale expression and purification of the hMAT2A-K289L mutant followed the same protocol as the wild type. ${ }^{3}$ Purified hMAT2A-K289L mutant protein at a concentration of $10-20 \mathrm{mg} \mathrm{mL}^{-1}$ in a buffer containing 50mM HEPES, pH 7.5, $10 \mathrm{mM}$ Metol, $5 \mathrm{mM}$ magnesium chloride, $2 \mathrm{mM}$ ADP was mixed with a reservoir solution in a $200 \mathrm{~nL}: 200 \mathrm{~nL}$ sitting drop crystallization trail. Hits were obtained using the IndexHT screen (Hampton Research, Aliso Viejo, CA) setup with a Mosquito liquid handling robot (TTP Labtech). The best crystals were produced using a reservoir containing $0.2 \mathrm{M} \mathrm{KCl}, 0.05 \mathrm{M} \mathrm{HEPES} \mathrm{pH7.5,35 \% (v/v)}$ pentaeythritol propoxylate $(5 / 4 \mathrm{PO} / \mathrm{OH})$. They were harvested after 7 months using $100 \mu \mathrm{m}$ Dual Thickness MicroMounts (MiTeGen, Ithaca, NY) under silicon oil (Hampton Research, Aliso Viejo, CA) and plungecooled in liquid nitrogen. Data were collected with a Rayonix MX-300 CCD detector (Evanston, IL) on LSCAT beamline 21-ID-F at the Advanced Photon Source (APS, Argonne National Lab). Data were integrated, reduced and scaled using $X D S^{4,5}$ followed by anisotropic analysis, elliptical truncation and merging using STARANISO. ${ }^{6}$ The resolution limits of the cutoff surface were $2.8 \AA, 1.8 \AA$ and $2.1 \AA$ along the $a^{*}, b^{*}$ and $c^{*}$ axes with a maximum resolution limit of $2.05 \AA$. Since the data are incomplete to $2.05 \AA$, we define the nominal resolution as $2.30 \AA$, which is the resolution of a dataset that is $100 \%$ complete and has the same number of reflections as observed in dataset after applying the cutoff. ${ }^{7}$ Nevertheless, there are 2618 reflections observed between 2.05 and $2.30 \AA$ (39.1\% complete for this shell) included in the refinement. Model completion and refinement were performed with Coot, ${ }^{8}$ phenix.refine ${ }^{9}$ and Buster. ${ }^{10}$ The crystals were isomorphous with the higher resolution wild-type structure (PDB: 2p02), ${ }^{11}$ which was used for the initial phasing. Refinement included torsion-angle, reference model restraints derived from the 2p02 structure and TLS refinement with one TLS group for the protein. Comparison of the final model to the 2p02 reference model has an RMSD 0.34 for all 2983 matching atoms and 0.25 for the 393 matching $\mathrm{C} \alpha$ atoms. Data-reduction and refinement statistics are summarized in supplemental Table S1 and binding pocket density is shown in Figure S3.

\section{Supplementary references.}

(1) Huber, T. D., Wang, F., Singh, S., Johnson, B. R., Zhang, J., Sunkara, M., Van Lanen, S. G., Morris, A. J., Phillips, G. N., and Thorson, J. S. (2016) Functional AdoMet isosteres resistant to classical AdoMet degradation pathways. ACS Chem. Biol. 11, 2484-2491.

(2) Hoye, T. R., Jeffrey, C. S., and Shao, F. (2007) Mosher ester analysis for the determination of absolute configuration of stereogenic (Chiral) carbinol carbons. Nat. Protoc. 2, 2451-2458.

(3) Singh, S., Zhang, J., Huber, T. D., Sunkara, M., Hurley, K., Goff, R. D., Wang, G., Zhang, W., Liu, C., Rohr, J., Van Lanen, S. G., Morris, A. J., and Thorson, J. S. (2014) Facile chemoenzymatic strategies for the synthesis and utilization of S-adenosyl-L-methionine analogues. Angew. Chemie Int. Ed. 53, 39653969.

(4) Kabsch, W. (2010) XDS. Acta Crystallogr. D66, 125-132. 
(5) Kabsch, W. (2010) Integration, scaling, space-group assignment and post-refinement. Acta Crystallogr. D66, 133-144.

(6) Tickle, I. J., Flensburg, C., Keller, P., Paciorek, W., Sharff, A., Vonrhein, C., and Bricogne, G. (2018) STARANISO. http://staraniso.globalphasing.org/cgi-bin/staraniso.cgi. Global Phasing Ltd., Cambridge, United Kingdom.

(7) Kleywegt, G. J. (2000) Validation of protein crystal structures. Acta Crystallogr. D56, 249-265.

(8) Emsley, P., Lohkamp, B., Scott, W. G., and Cowtan, K. (2010) Features and development of Coot. Acta Crystallogr. D. Biol. Crystallogr. 66, 486-501.

(9) Adams, P. D., Afonine, P. V, Bunkóczi, G., Chen, V. B., Davis, I. W., Echols, N., Headd, J. J., Hung, L.-W., Kapral, G. J., Grosse-Kunstleve, R. W., McCoy, A. J., Moriarty, N. W., Oeffner, R., Read, R. J., Richardson, D. C., Richardson, J. S., Terwilliger, T. C., and Zwart, P. H. (2010) PHENIX: A comprehensive Python-based system for macromolecular structure solution. Acta Crystallogr. D66, 213221.

(10) Bricogne, G., Blanc, E., Brandl, M., Flensburg, C., Keller, P., Paciorek, W., Roversi, P., Sharff, A., Smart, O. S., Vonrhein, C., and Womack, T. O. (2017) BUSTER. Global Phasing Ltd., Cambridge, United Kingdom.

(11) Shafqat, N., Muniz, J. R. C., Pilka, E. S., Papagrigoriou, E., von Delft, F., Oppermann, U., and Yue, W. W. (2013) Insight into S-adenosylmethionine biosynthesis from the crystal structures of the human methionine adenosyltransferase catalytic and regulatory subunits. Biochem. J. 452, 27-36.

(12) Liebschner, D., Afonine, P. V., Moriarty, N. W., Poon, B. K., Sobolev, O. V., Terwilliger, T. C., and Adams, P. D. (2017) Polder maps: improving OMIT maps by excluding bulk solvent. Acta Crystallogr. D73, 148-157.

(13) Diederichs, K., and Karplus, P. A. (1997) Improved R-factors for diffraction data analysis in macromolecular crystallography. Nat. Struct. Biol. 4, 269-275.

(14) Chen, V. B., Arendall, W. B., Headd, J. J., Keedy, D. A., Immormino, R. M., Kapral, G. J., Murray, L. W., Richardson, J. S., and Richardson, D. C. (2010) MolProbity: All-atom structure validation for macromolecular crystallography. Acta Crystallogr. D66, 12-21. 
A

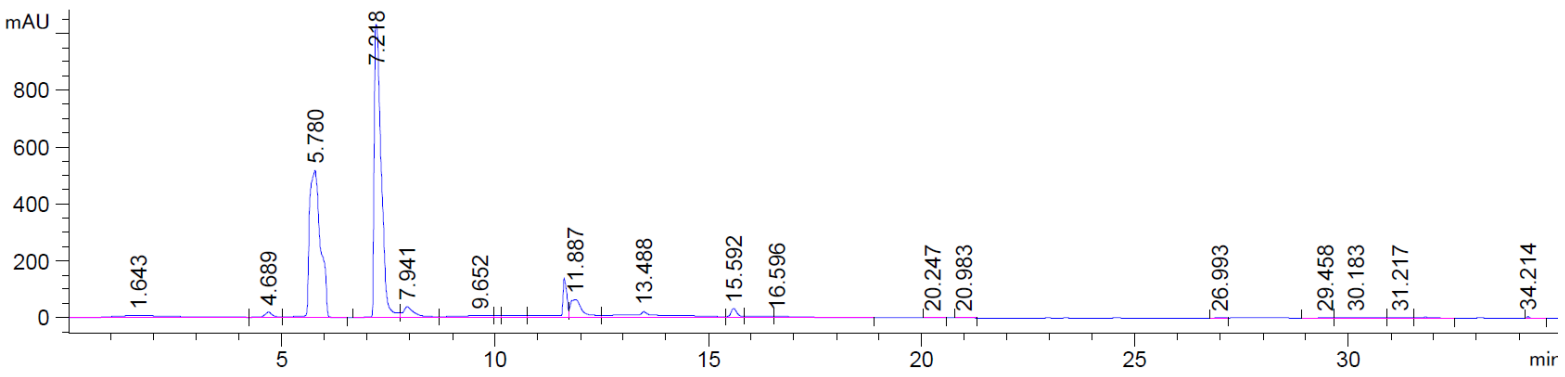

B

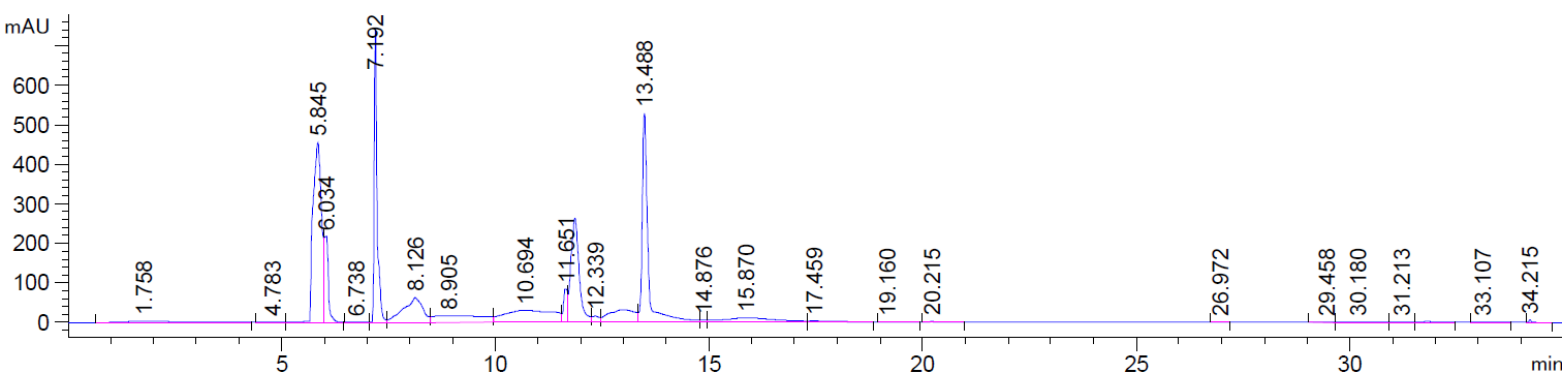

C

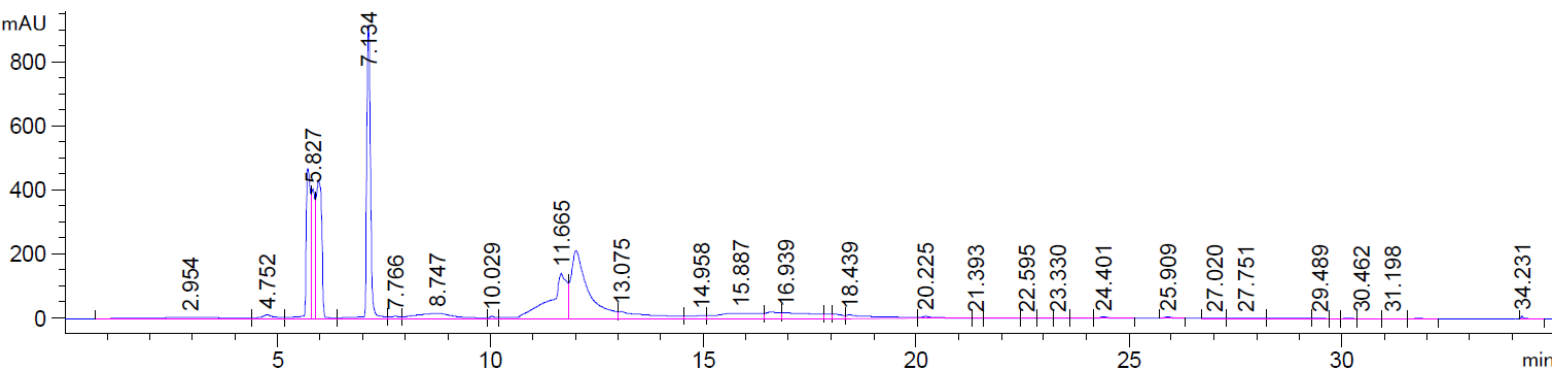

Figure S1. Representative analytical HPLC at $\mathrm{A}_{260}$. (A) hMAT2A mutant K289L $(10 \mu \mathrm{M})$ with $10 \mathrm{mM}$ metol and $2 \mathrm{mM}$ ATP after $24 \mathrm{hr}$, highlighting the lack of MTA (13.5 min) production. (B) hMAT2A mutant K289L $(10 \mu \mathrm{M})$ with $10 \mathrm{mM}$ L-Met and $2 \mathrm{mM} \mathrm{ATP}$ after $24 \mathrm{hr}$, highlighting notable production of MTA (13.5 min). (C) hMAT2A mutant K289F $(10 \mu \mathrm{M})$ with $10 \mathrm{mM} R, S$-metolMe and $2 \mathrm{mM}$ ATP after $24 \mathrm{hr}$, highlighting the lack of MTA (13.5 min) production. AdoMet analogues (5.8 min), adenine (7.2 min), ATP (11.6 min), MTA (13.5 min). 
A

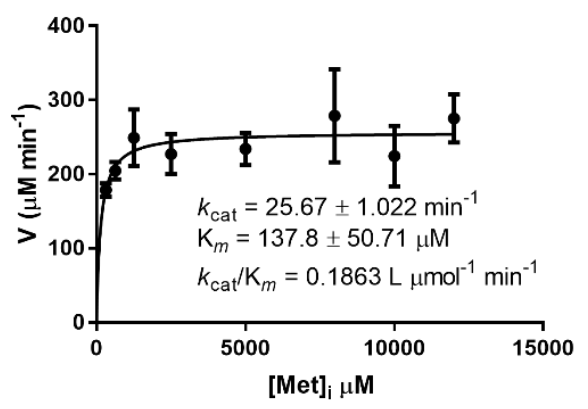

C

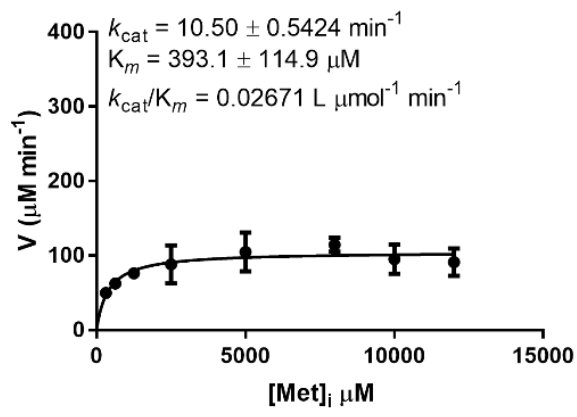

$\mathbf{E}$

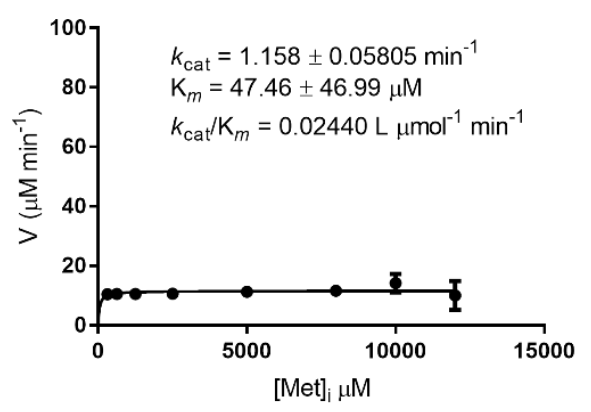

G

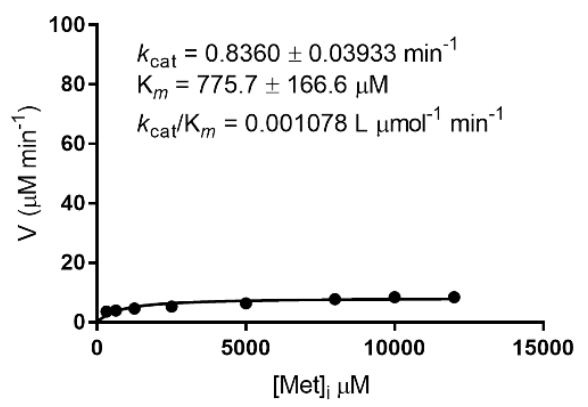

B

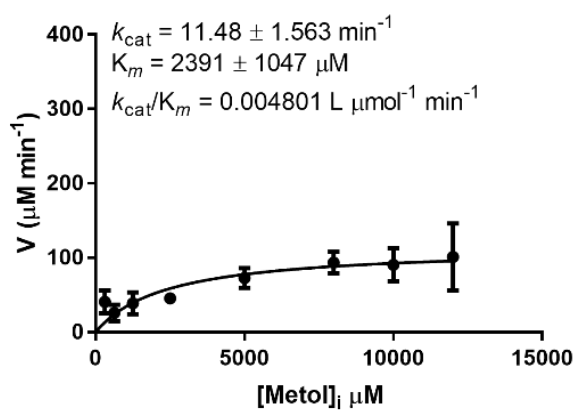

D

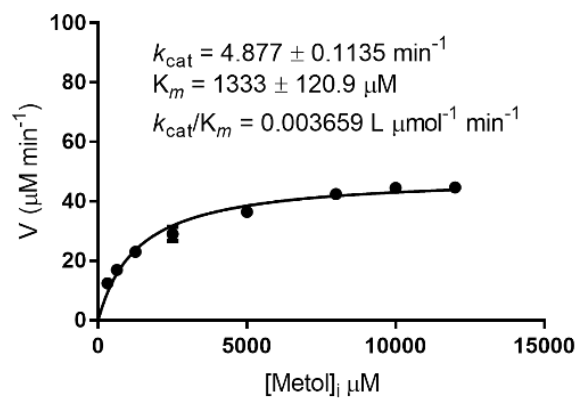

$\mathbf{F}$

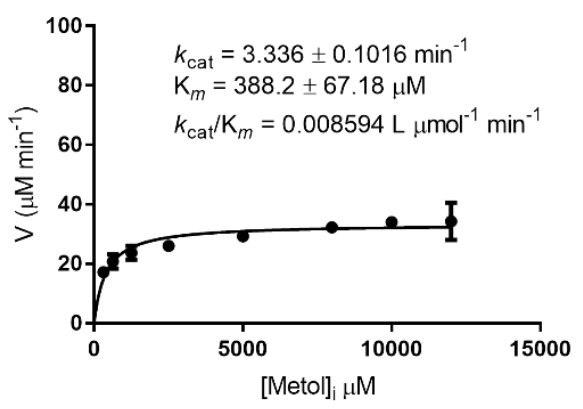

H

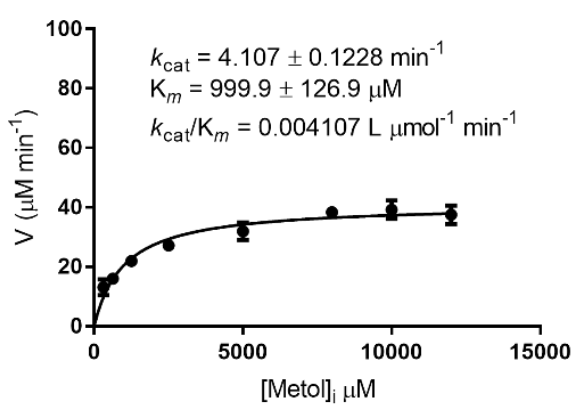

Figure S2. Determination of kinetic parameters for mutant and wt-hMAT2A-catalyzed reactions. [hMAT2A or hMAT2A mutant] $=10 \mu \mathrm{M}$ and $[\text { ATP }]_{i}=2000 \mu \mathrm{M}$ in all experiments. (A) wt-hMAT2A, [Met $]_{i}$ $=$ varied. $(B)$ wt-hMAT2A, [Metol $]_{i}=$ varied. (C) hMAT2A mutant E70S, $[\text { Met }]_{i}=$ varied. (D) hMAT2A mutant K289S, [Metol] $]_{i}=$ varied. (E) hMAT2A mutant Q113D, [Met] $]_{i}=$ varied. (F) hMAT2A mutant Q113D, [Metol] ${ }_{i}=$ varied. (G) hMAT2A mutant K289L, [Met $]_{i}=$ varied. (H) hMAT2A mutant K289L, [Metol] $=$ varied. 
A

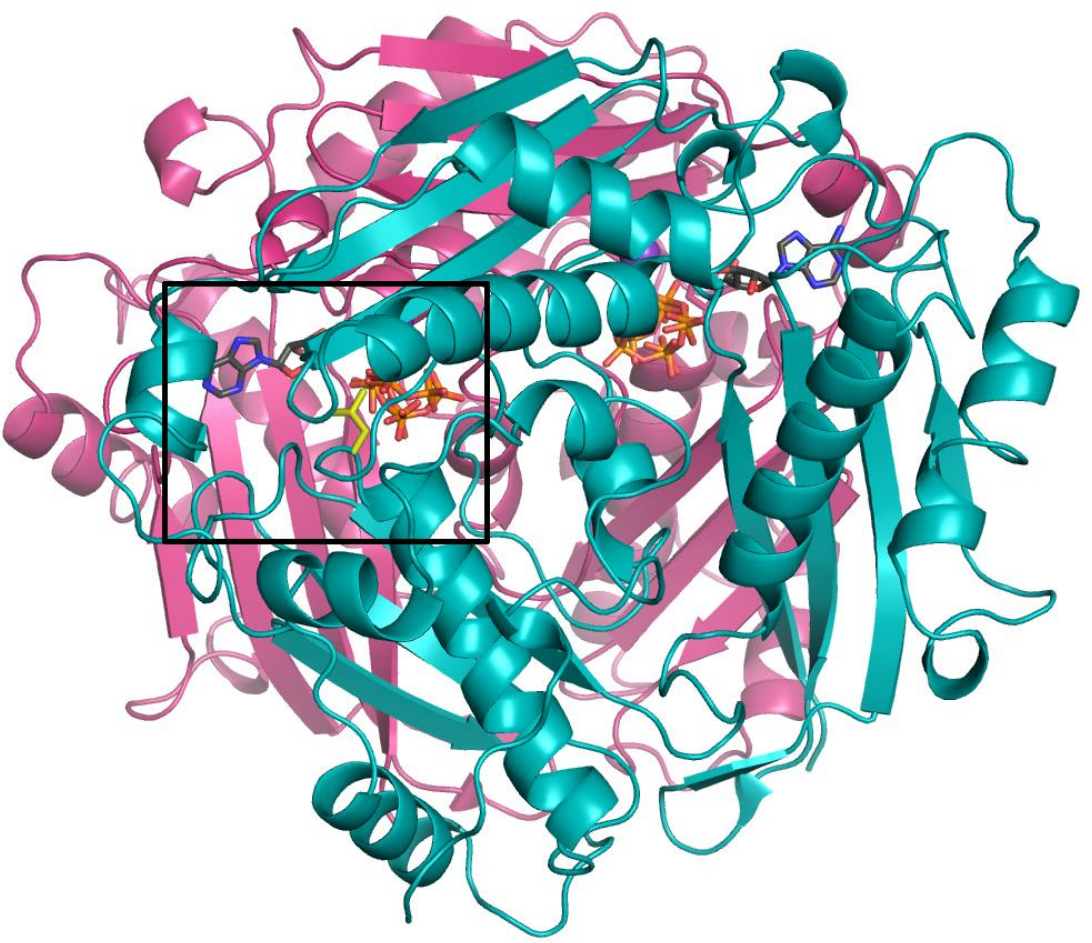

B
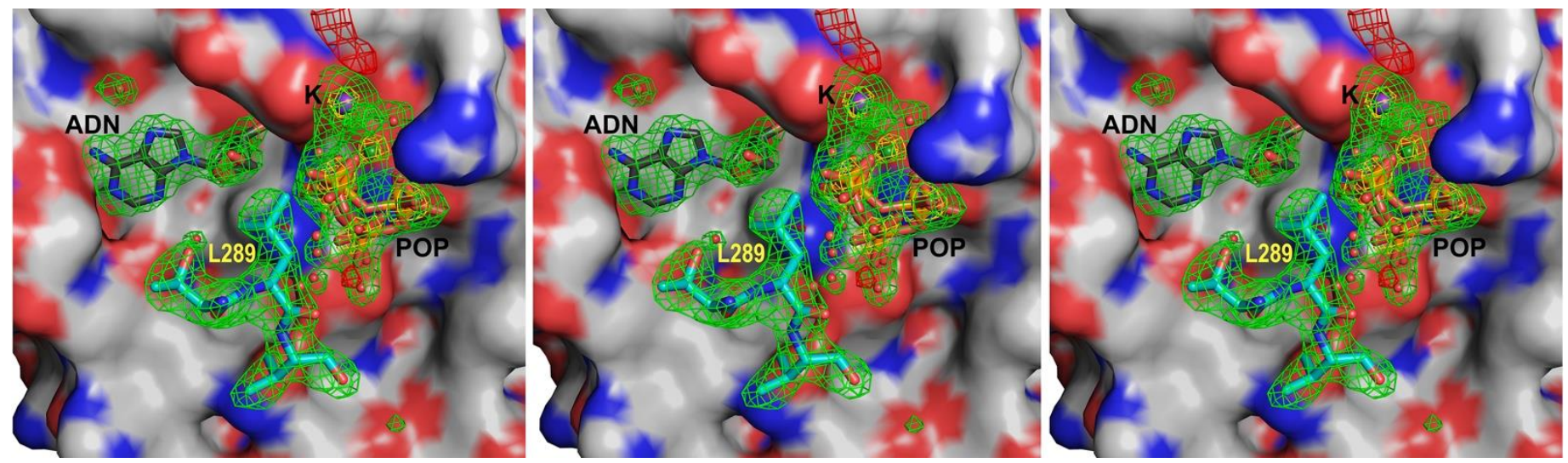

Figure S3. hMAT2A-K289L electron density map. (A) Ribbon diagram of the hMAT2A-K289L dimer with the $\mathrm{L} 289$ residue highlighted in yellow. (B) Stereo triptych (left-right-left) showing the hMAT2A-K289L $m F o-$ $D F c$ polder omit electron density map ${ }^{12}$ contoured at +3.2 (green), +8.0 (yellow) and -3.2 (red) r.m.s.d. The residues adjacent to and including the mutation 288-TLV-290 (cyan carbons) as well as the adenosine (gray carbons), disordered pyrophosphate (red and orange), magnesium ion (green), potassium ion (purple) and nearby waters were omitted from the polder map calculation. The orientation is the same as (A) with the magenta protomer shown in surface representation and only the omitted 288-TLV-290 tripeptide shown from the cyan protomer for clarity. 


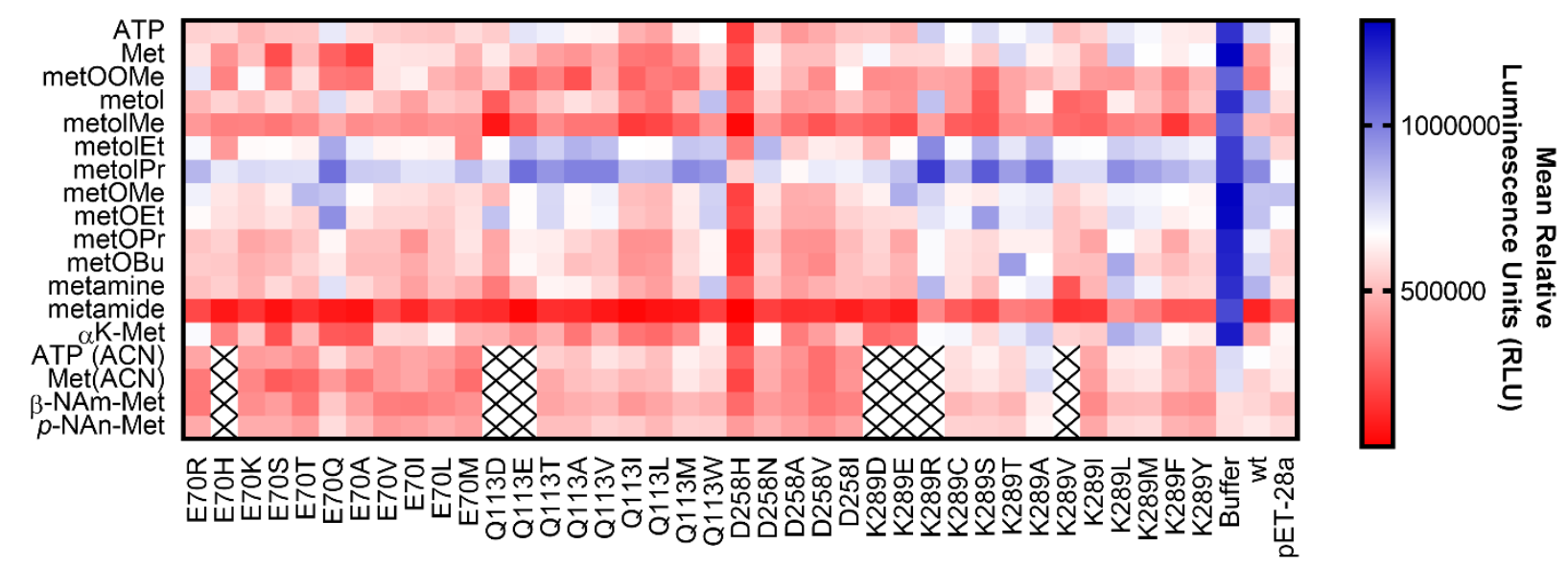

Figure S4. Combinatorial plate-based screen of targeted hMAT2A mutants with L-Met analogues highlighted in Figure 2. The heat map compares the relative activity of hMAT2A mutant (y-axis) and L-Met analogue (x-axis) pairings. The color of each square is dependent on the measured mean relative luminescence units (RLU) under experimental conditions for that mutant. Red corresponds to lower observed luminescence (i.e., lower [ATP]) as an indirect measure of turnover; blue indicates higher observed luminescence (i.e., higher [ATP]) as an indirect measure of lack of turnover; X, not tested. Standard assay conditions: $10 \mathrm{mM}$ L-Met analogue, $1.5 \mathrm{mM}$ ATP, $37^{\circ} \mathrm{C}, 60 \mathrm{~min}$. 
Table S1. Summary of crystal parameters, data collection, and refinement statistics. Elliptically truncated data from STARANISO was used for the final refinement.

\begin{tabular}{|c|c|c|}
\hline Crystal parameters & hMAT2A - K289L & \\
\hline Space group & 1222 & \\
\hline Unit-cell lengths $(\AA ̊)$ & $60.6,104.1,63.0$ & \\
\hline Data collection statistics & after elliptical trimming & before elliptical trimming \\
\hline Wavelength $(\AA)$ & 0.98 & \\
\hline Resolution range $(\AA)$ & $40-2.05$ & $40-2.05$ \\
\hline High Resolution bin range $(\AA)$ & $(2.22-2.05)$ & $(2.22-2.05)$ \\
\hline No. of observations measured & $146,211(14,326)$ & $199,742(37,145)$ \\
\hline No. of unique reflections & $16,840(1,684)$ & $23,368(4,770)$ \\
\hline Completeness spherical (\%) & $72.0(35.9)$ & $99.9(99.4)$ \\
\hline Completeness elliptical (\%) & $93.9(85.7)$ & \\
\hline $\mathrm{R}_{\text {merge }}{ }^{a}$ & $0.194(1.66)$ & $0.254(2.93)$ \\
\hline$R_{\text {meas }}^{b}$ & $0.207(1.76)$ & $0.270(3.14)$ \\
\hline Redundancy & $8.7(8.5)$ & $8.6(7.8)$ \\
\hline Mean I / sigma (I) & $9.3(1.4)$ & $6.9(0.7)$ \\
\hline $\mathrm{CC}_{1 / 2}{ }^{\mathrm{c}}$ & $1.00(0.42)$ & $1.00(0.34)$ \\
\hline \multicolumn{3}{|l|}{ Refinement and model statistics } \\
\hline$R_{\text {cryst }} / R_{\text {free }}{ }^{d}$ & $0.174 / 0.203$ & \\
\hline No. of reflections (total / test) & $16,835 / 825$ & \\
\hline RMSD bonds $(\AA)$ & 0.002 & \\
\hline RMSD angles $\left({ }^{\circ}\right)$ & 0.64 & \\
\hline No. of protein atoms & 5,137 & \\
\hline No. of waters & 158 & \\
\hline No. of auxiliary molecules & denosine, 1 pyrophosphate, $1 \mathrm{mac}$ & $\mathrm{n}$ ion, 1 potassium ion \\
\hline Ligands RSCC ${ }^{e}$ & $0.93 / 0.98 / 0.99 / 1$ & \\
\hline B factor - protein/ligand/solvent $\left(\AA^{2}\right)$ & 37.5 / 39.5 / 36.5 & \\
\hline All atom clashscore ${ }^{f}$ & 2.3 & \\
\hline Protein RMSD to reference $2 \mathrm{P} 02(\AA \AA$ all $/ \mathrm{C}$ & $0.34 / 0.25$ & \\
\hline \multicolumn{3}{|l|}{ Ramachandran plot (\%) } \\
\hline Favored / allowed / disallowed regions ${ }^{t}$ & $97.1 / 2.9 / 0.0$ & \\
\hline PDB & $6 \mathrm{PgV}$ & \\
\hline
\end{tabular}

${ }^{a} R_{\text {merge }}=\sum h \sum_{i}\left|I_{i}(h)-<\right|(h)>\mid / \sum h \sum_{i} l_{i}(h)$, where $l_{i}(h)$ is the intensity of an individual measurement of the reflection and $<\mathrm{l}(\mathrm{h})>$ is the mean intensity of the reflection.

${ }^{b} R_{\text {meas }}=\sum_{\mathrm{h}}[\mathrm{N} /(\mathrm{N}-1)]^{1 / 2} \sum_{\mathrm{i}}\left|\mathrm{l}_{\mathrm{i}}(\mathrm{h})-<\mathrm{l}(\mathrm{h})>\right| / \sum_{\mathrm{h}} \sum_{\mathrm{i}} \mathrm{l}_{\mathrm{i}}(\mathrm{h})$, is the Redundancy-independent merging $\mathrm{R}$ factor ${ }^{13}$ ${ }^{c} \mathrm{CC}_{1 / 2}=\sum(\mathrm{x}-\langle\mathrm{x}\rangle)(\mathrm{y}-\langle\mathrm{x}\rangle) /\left[\sum(\mathrm{x}-\langle\mathrm{x}\rangle)^{2} \sum(\mathrm{y}-\langle\mathrm{y}\rangle)^{2}\right]^{1 / 2}$

${ }^{d} R_{\text {cryst }}=\sum_{h} \| F_{\text {obs }}|-k| F_{\text {calc }}|| \sum \sum_{h}\left|F_{o b s}\right|$, where $F_{\text {obs }}$ and $F_{\text {calc }}$ are the observed and calculated structure factor amplitudes, respectively. $\mathrm{R}_{\text {free }}$, the same as $\mathrm{R}_{\text {cryst }}$, but for the $4.9 \%$ of reflections chosen at random and omitted from refinement.

eligand RSCC is ligand real-space correlation coefficient, which provides an objective measure of the fit of atom coordinates to electron density.

${ }^{f}$ as defined by molprobity. ${ }^{14}$ 
Spectroscopic Data
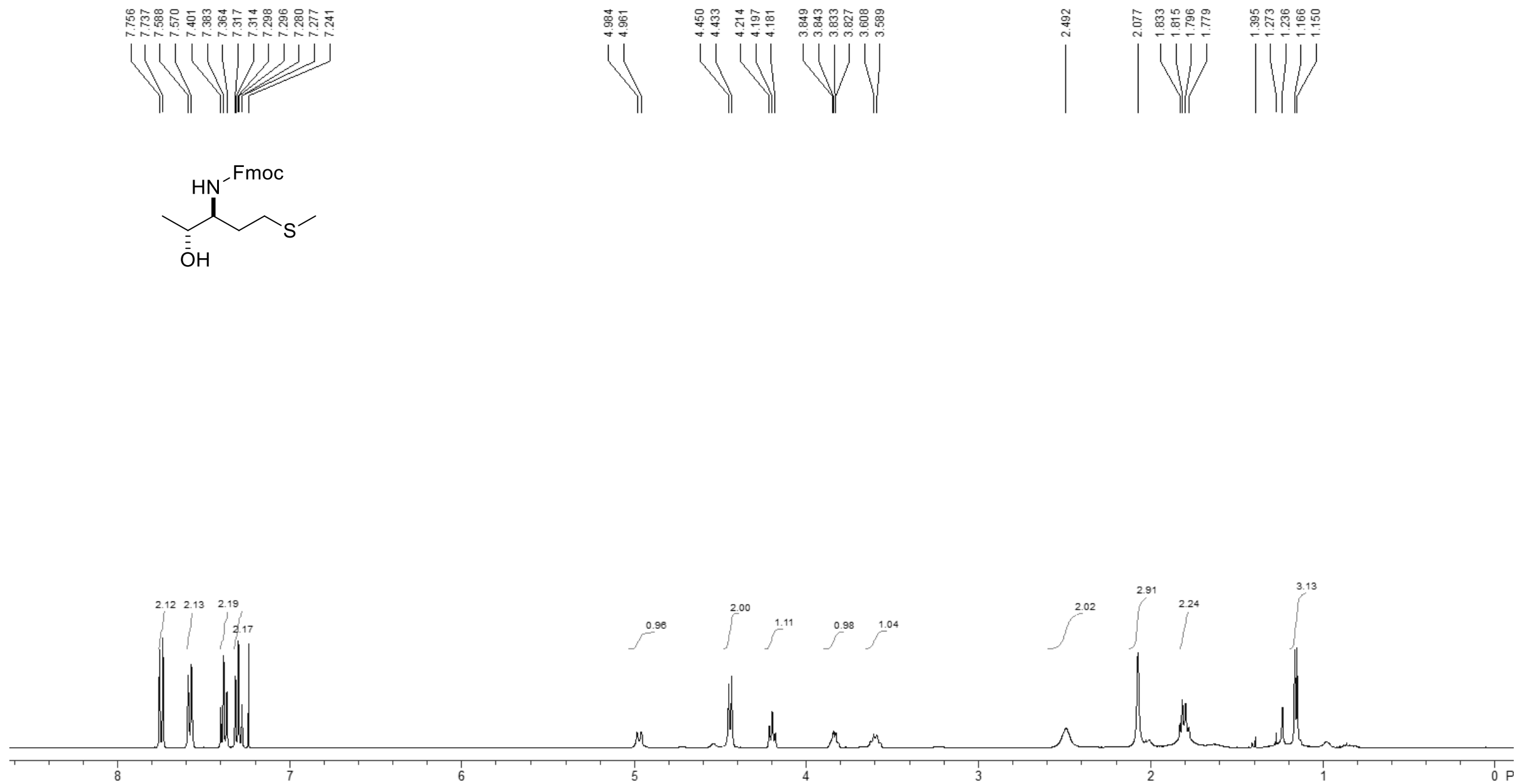

Figure S6. ${ }^{1} \mathrm{H} \mathrm{NMR}\left(400 \mathrm{MHz}, \mathrm{CDCl}_{3}\right)$ of $\boldsymbol{N}$-Fmoc- $\boldsymbol{R}, \mathbf{S}-\mathbf{4}$. 

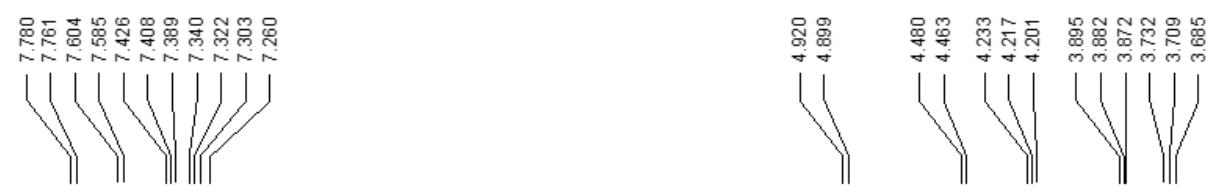

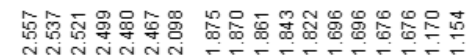
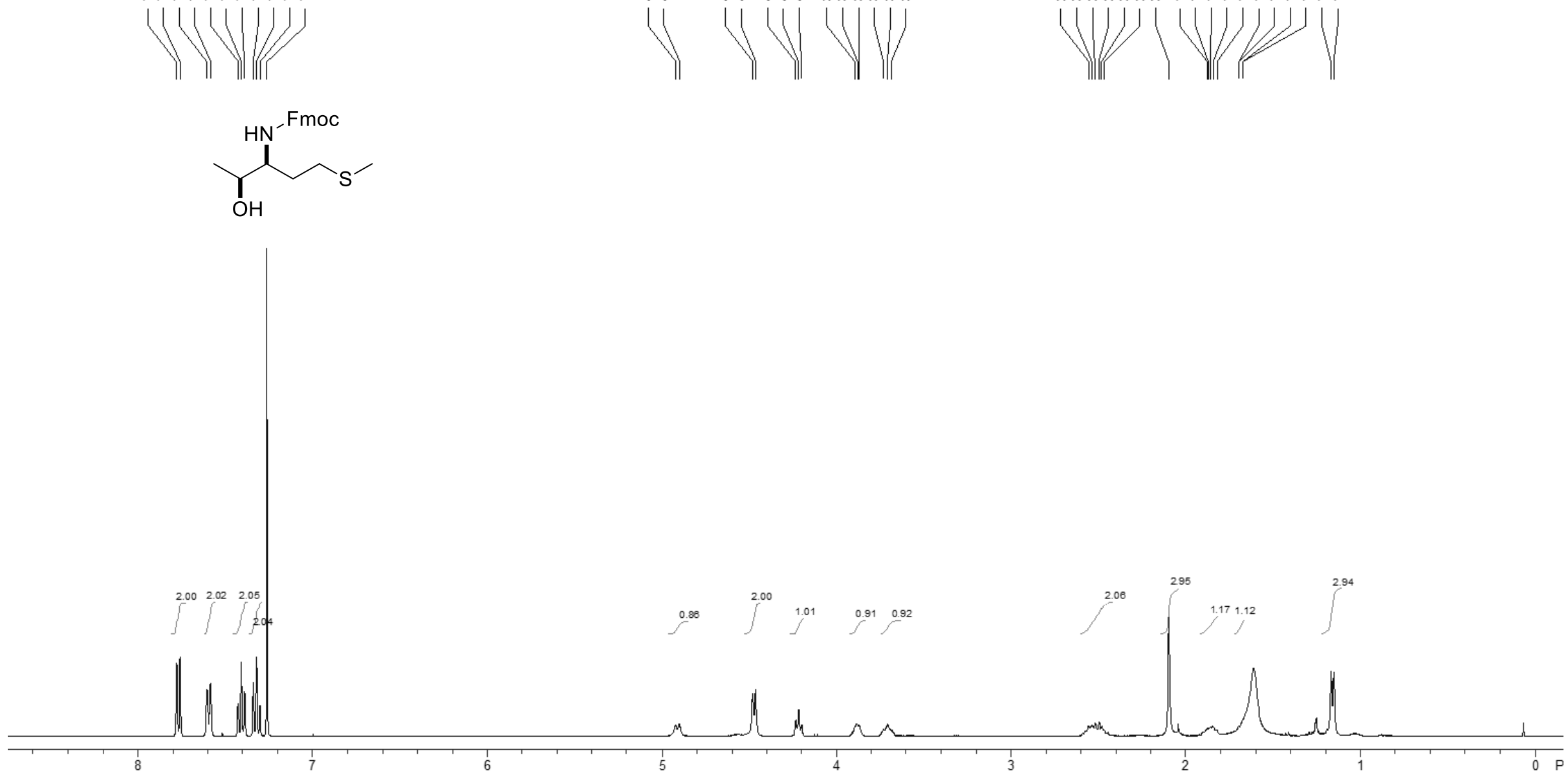

Figure S7. ${ }^{1} \mathrm{H}$ NMR $\left(400 \mathrm{MHz}, \mathrm{CDCl}_{3}\right)$ of $\mathbf{N}$-Fmoc-S, $\boldsymbol{S}-\mathbf{4}$. 

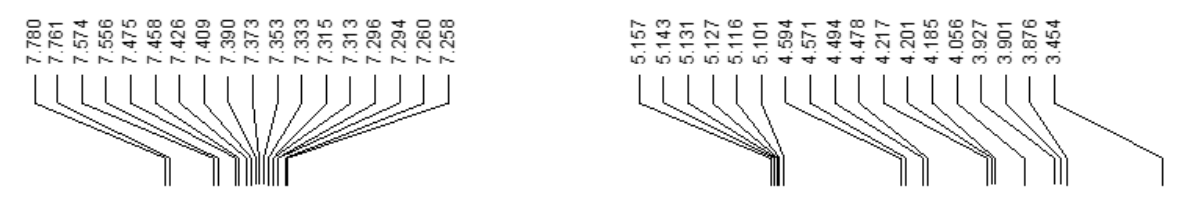

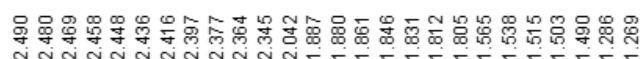

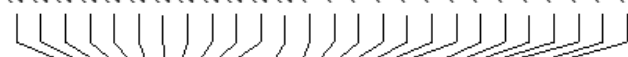

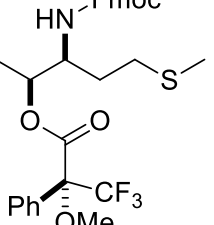

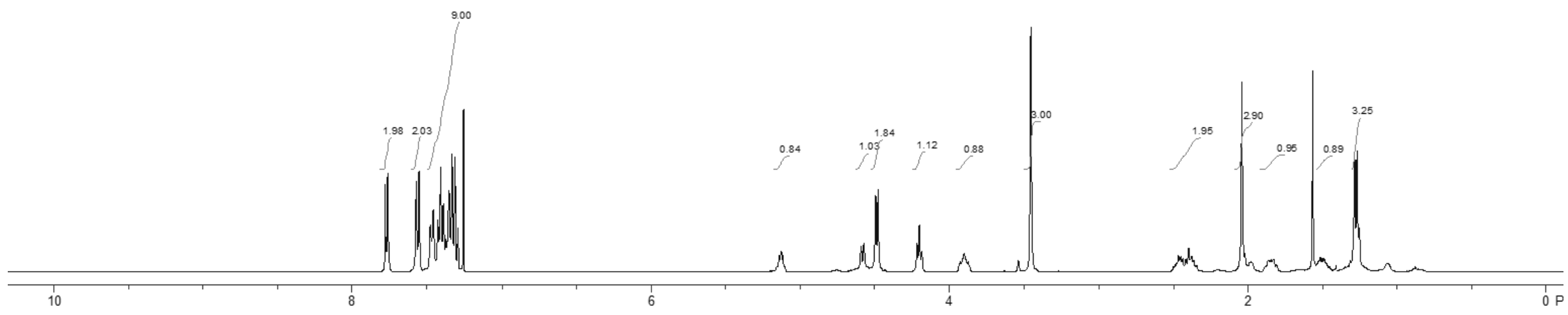

Figure S8. ${ }^{1} \mathrm{H}$ NMR (400 MHz, $\left.\mathrm{CDCl}_{3}\right)$ of $\boldsymbol{N}$-Fmoc-S,S-4-( $\left.\boldsymbol{R}\right)$-MTPA. 

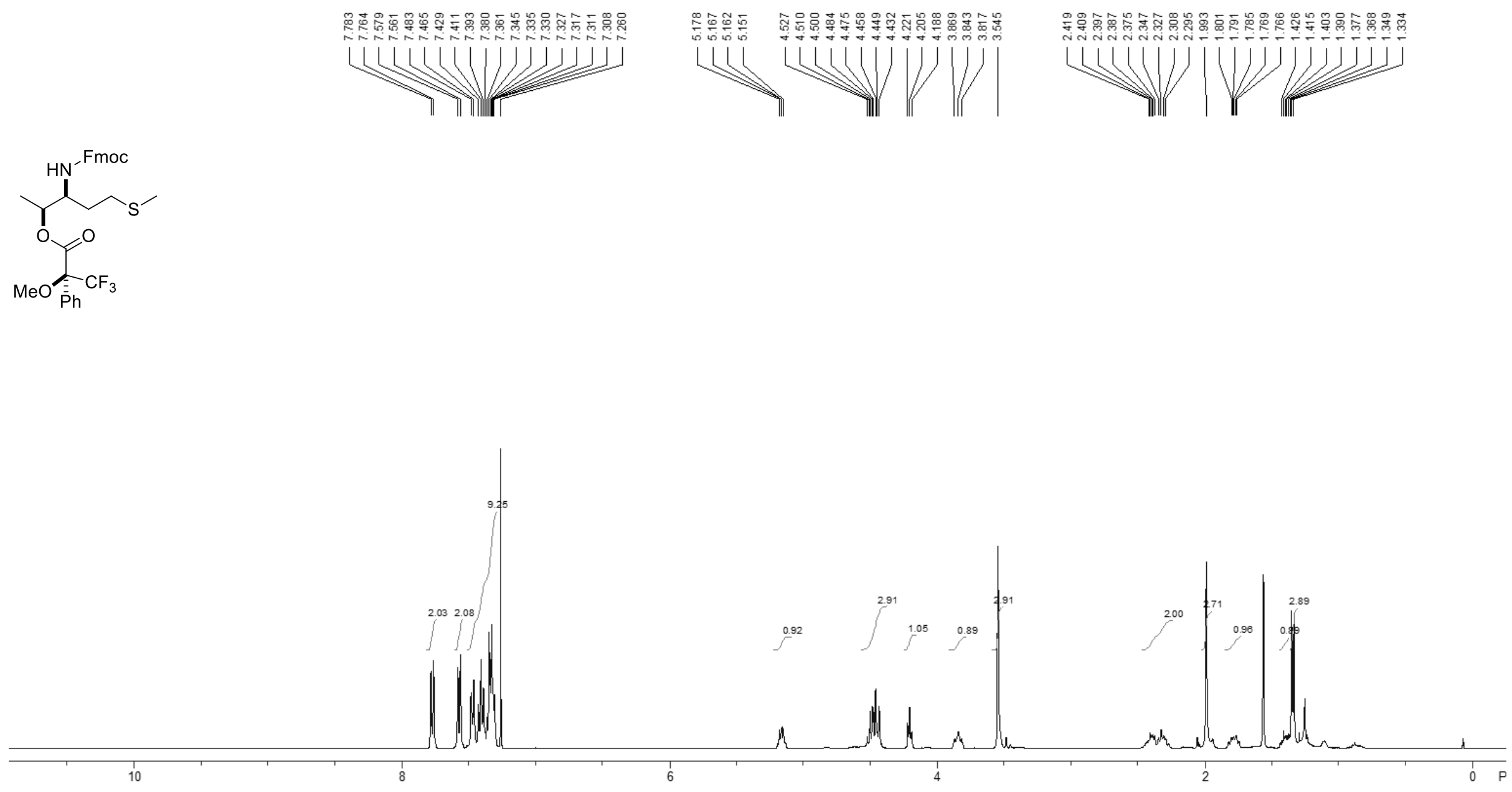

Figure S9. ${ }^{1} \mathrm{H}$ NMR (400 MHz, $\mathrm{CDCl}_{3}$ ) of $\boldsymbol{N}$-Fmoc-S,S-4-(S)-MTPA. 
<smiles>CSCCC(N)C(C)O</smiles>

$\mathrm{OH}$

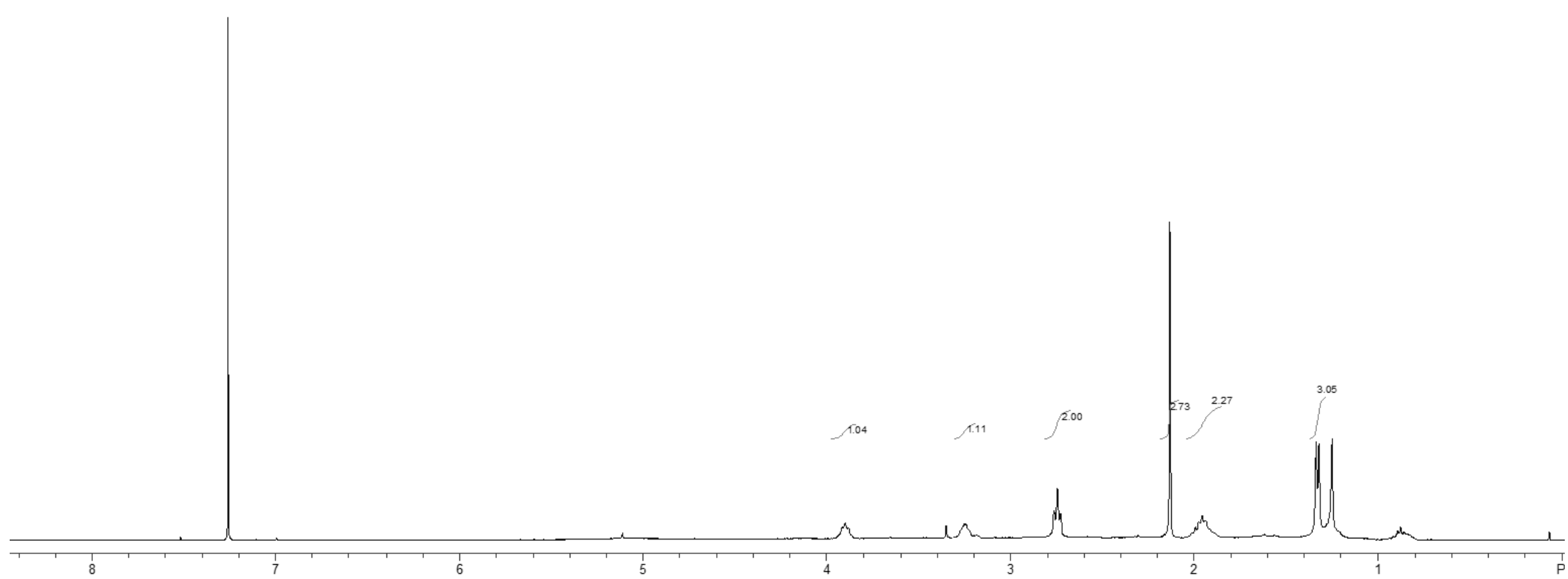

Figure S10. ${ }^{1} \mathrm{H}$ NMR $\left(400 \mathrm{MHz}, \mathrm{CDCl}_{3}\right)$ of $\boldsymbol{R}, \boldsymbol{s}-\mathbf{4}$. 

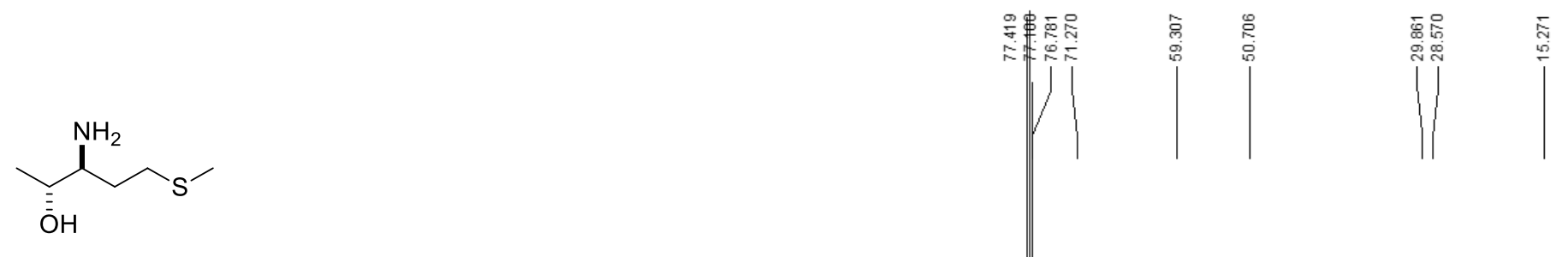

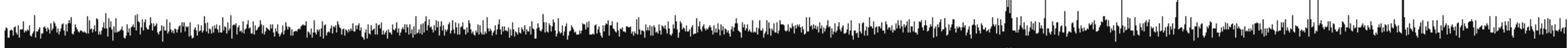

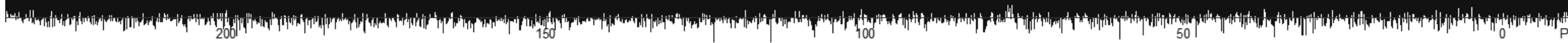

Figure S11. ${ }^{13} \mathrm{C}$ NMR $\left(100 \mathrm{MHz}, \mathrm{CDCl}_{3}\right)$ of $\boldsymbol{R}, \boldsymbol{S}-\mathbf{4}$ 

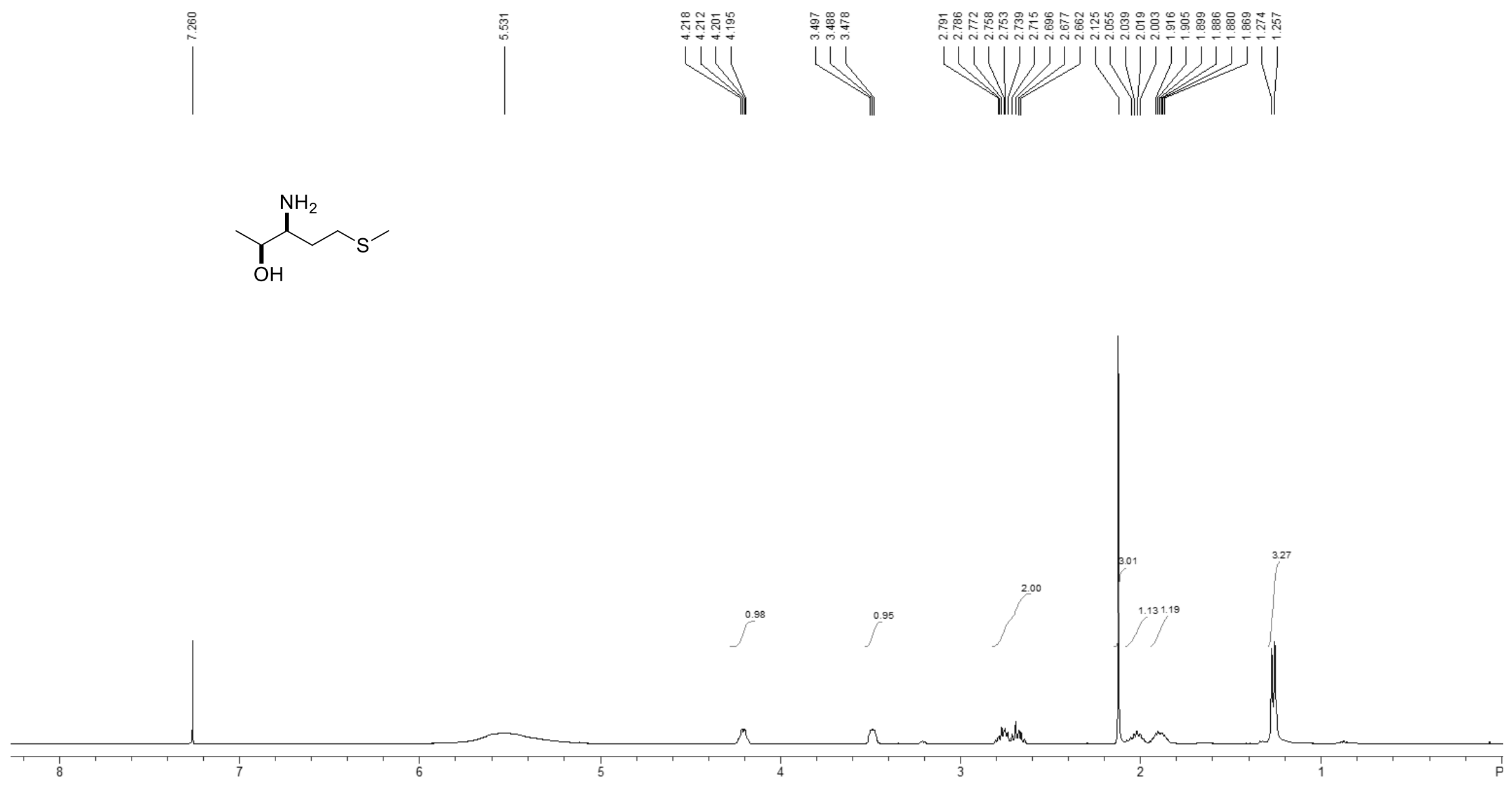

Figure S12. ${ }^{1} \mathrm{H}$ NMR $\left(400 \mathrm{MHz}, \mathrm{CDCl}_{3}\right)$ of $\mathbf{S}, \mathbf{S}-4$. 
$\overbrace{\mathrm{OH}^{\prime}}^{\mathrm{NH}_{2}}$

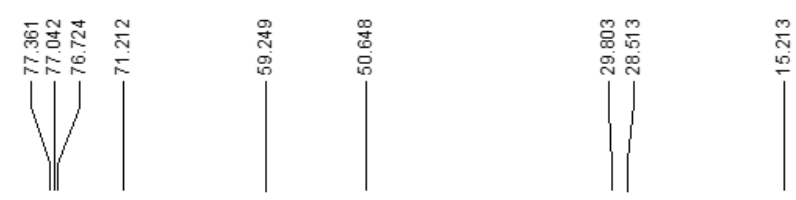

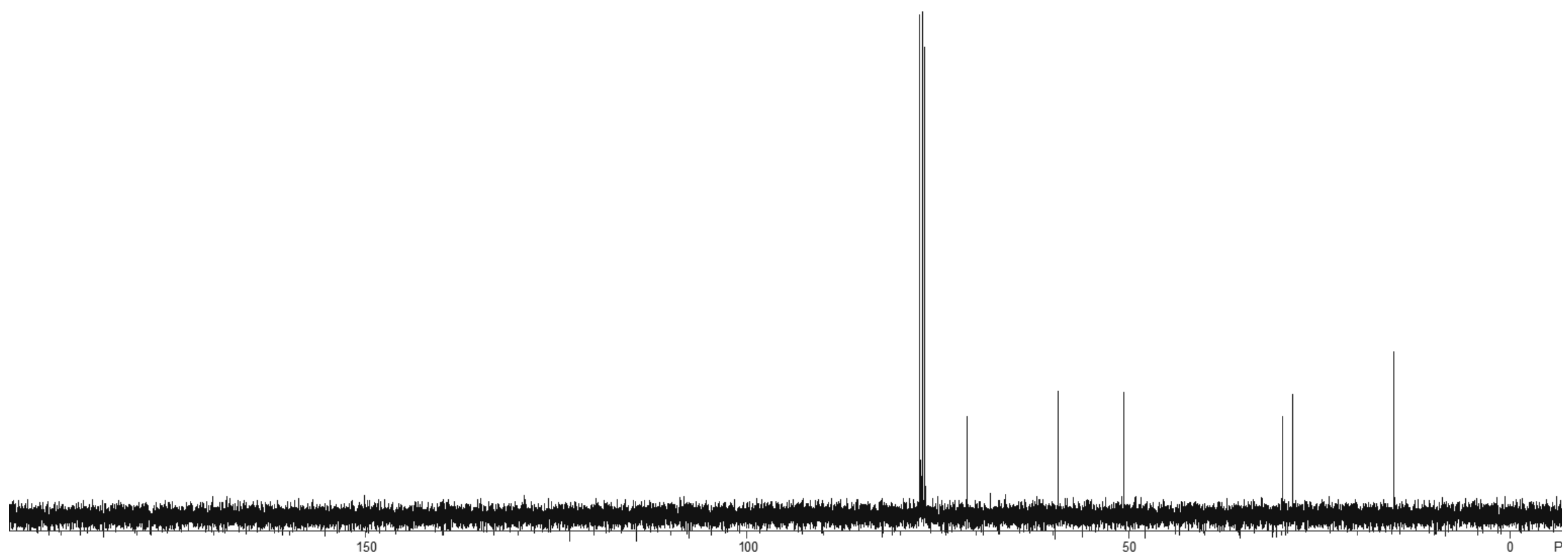

Figure $\mathbf{S} 13 .{ }^{13} \mathrm{C}$ NMR $\left(100 \mathrm{MHz}, \mathrm{CDCl}_{3}\right)$ of $\mathbf{S}, \mathbf{S}-\mathbf{4}$. 


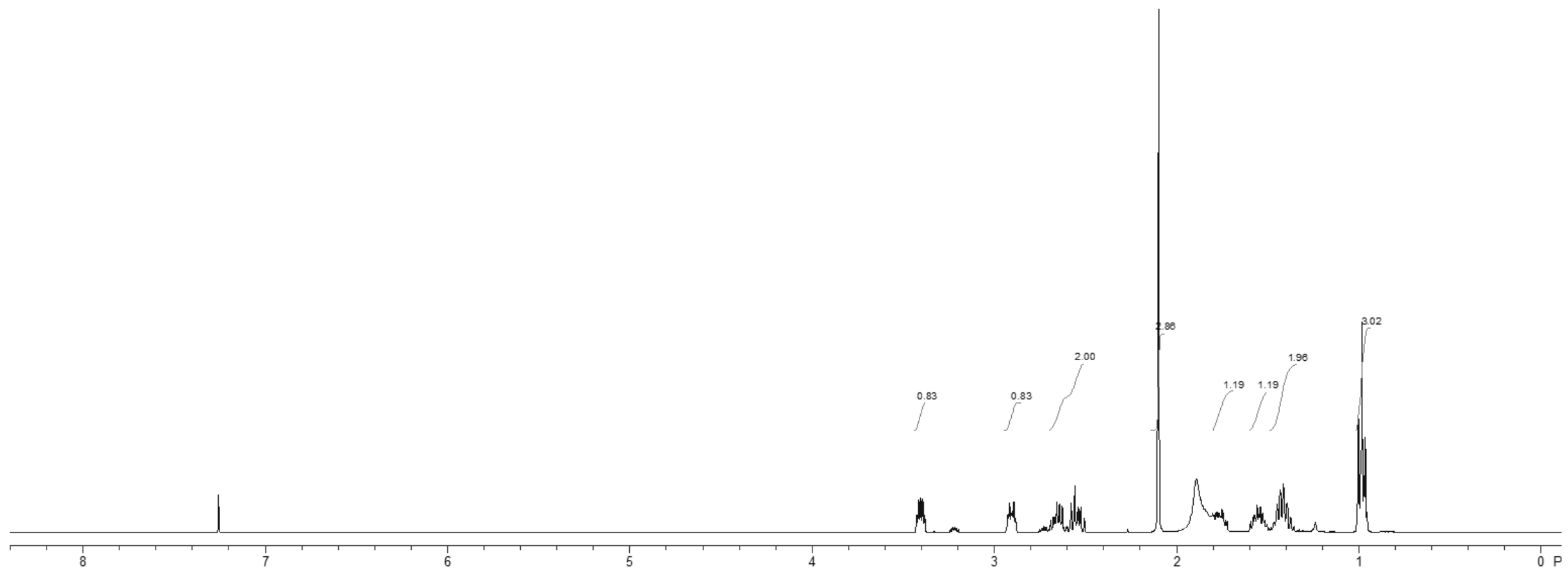

Figure S14. ${ }^{1} \mathrm{H} \mathrm{NMR}\left(400 \mathrm{MHz}, \mathrm{CDCl}_{3}\right)$ of 5. 

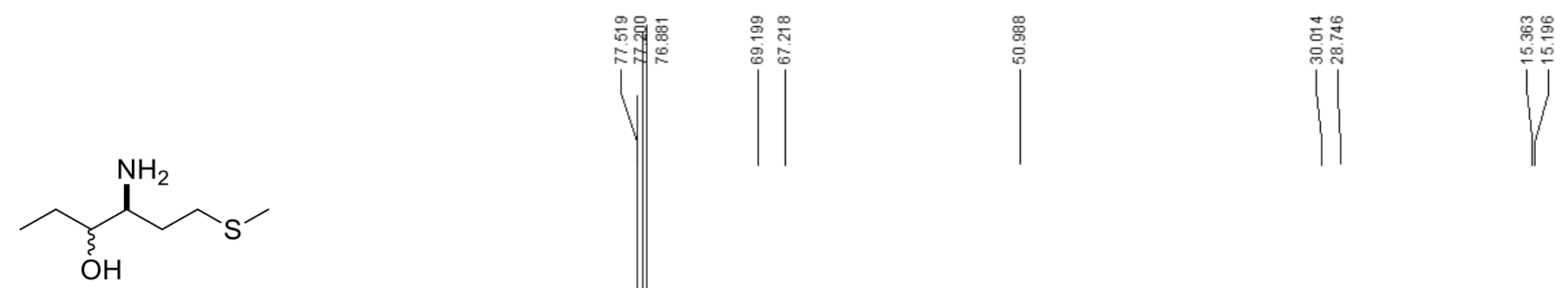

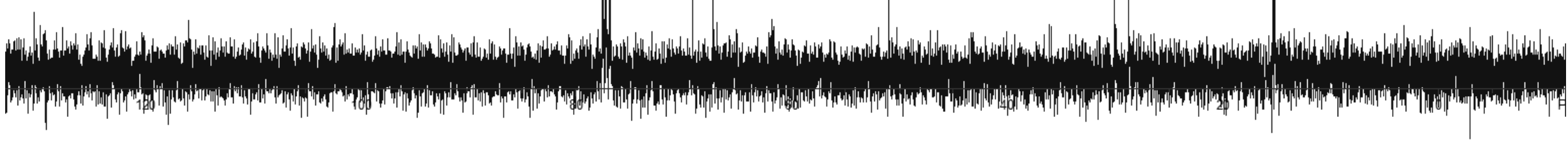

Figure S15. ${ }^{13} \mathrm{C}$ NMR $\left(100 \mathrm{MHz}, \mathrm{CDCl}_{3}\right)$ of 5. 

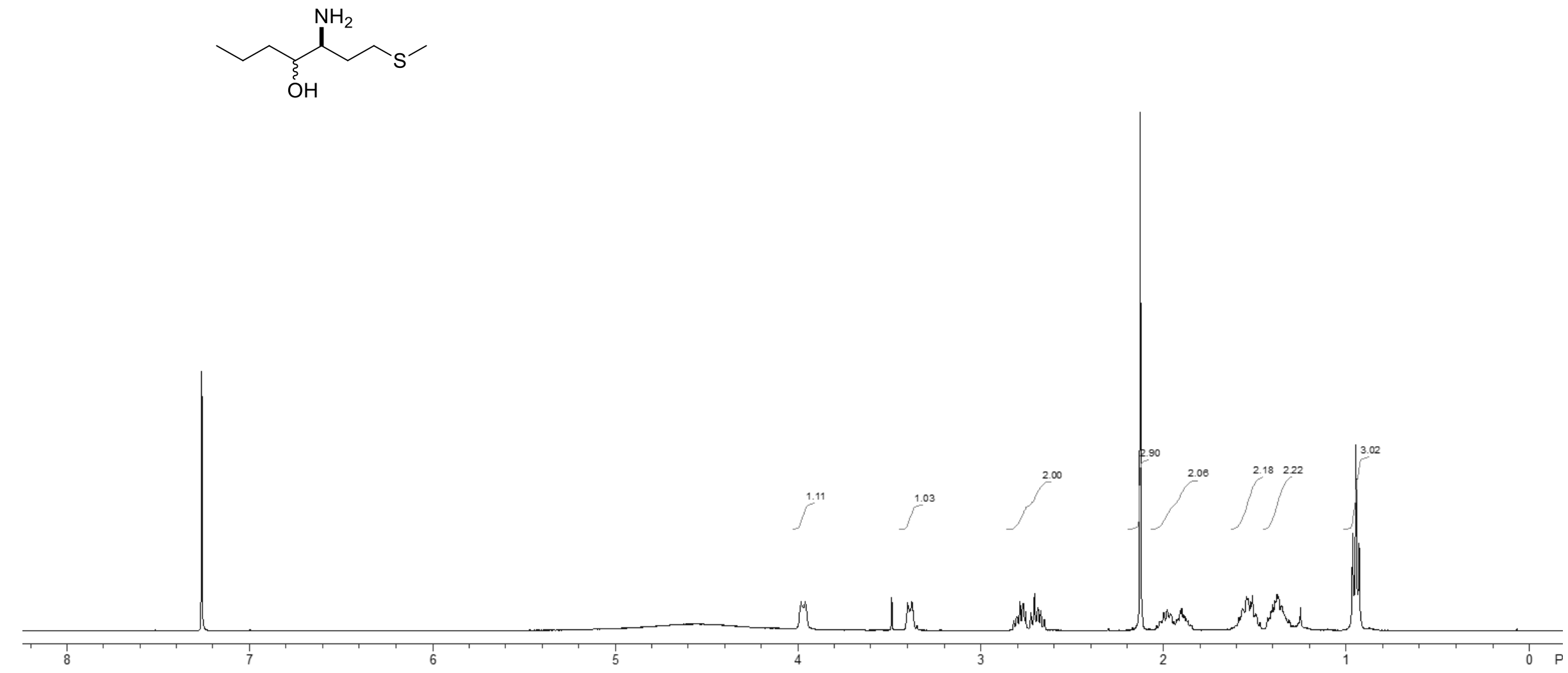

Figure S16. ${ }^{1} \mathrm{H} \mathrm{NMR}\left(400 \mathrm{MHz}, \mathrm{CDCl}_{3}\right)$ of 6. 

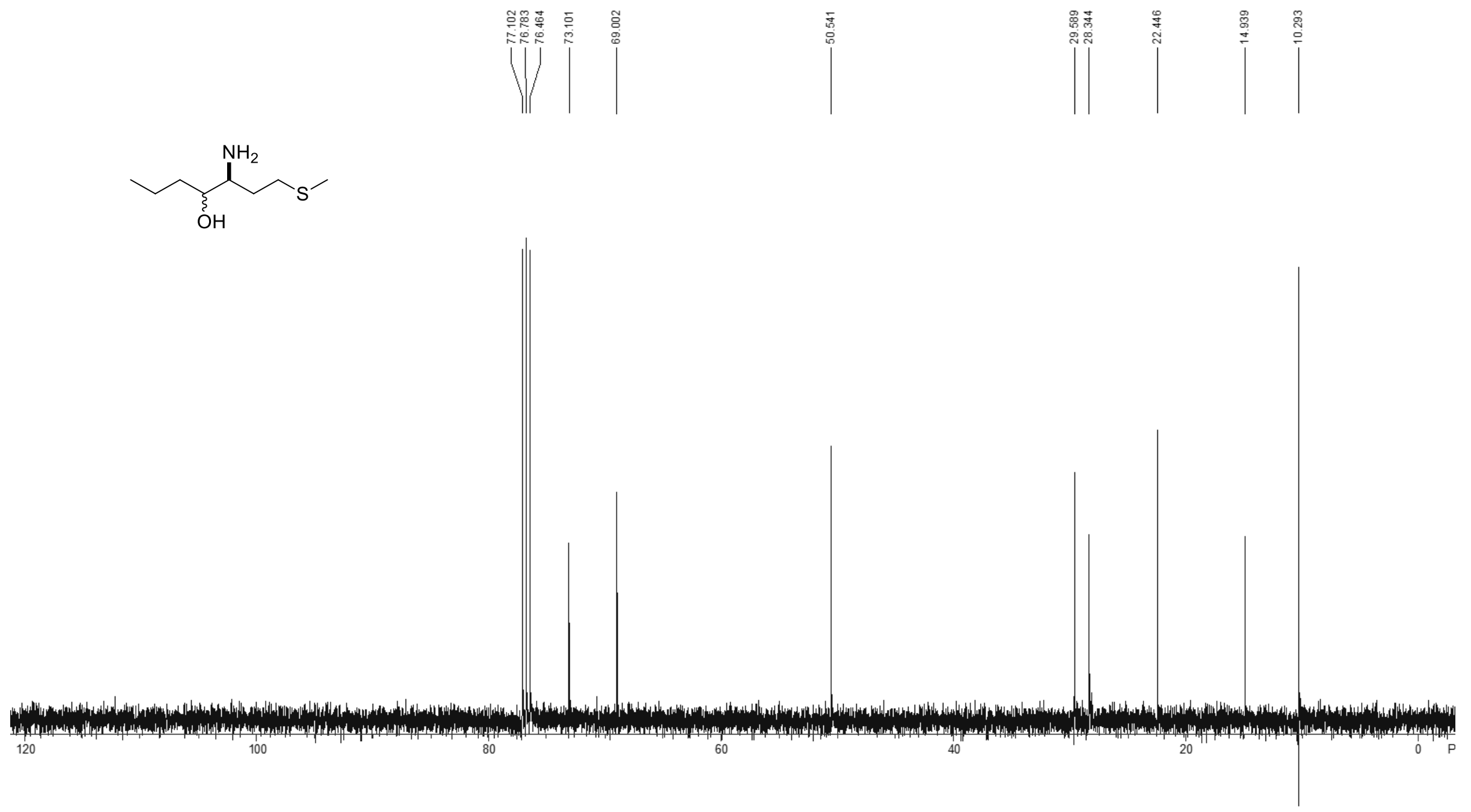

Figure S17. ${ }^{13} \mathrm{C} \mathrm{NMR}\left(100 \mathrm{MHz}, \mathrm{CDCl}_{3}\right)$ of 6 . 
$\mathrm{NH}_{2} \mathrm{HCl}$

$-\mathrm{C}_{\mathrm{S}^{\prime}}$

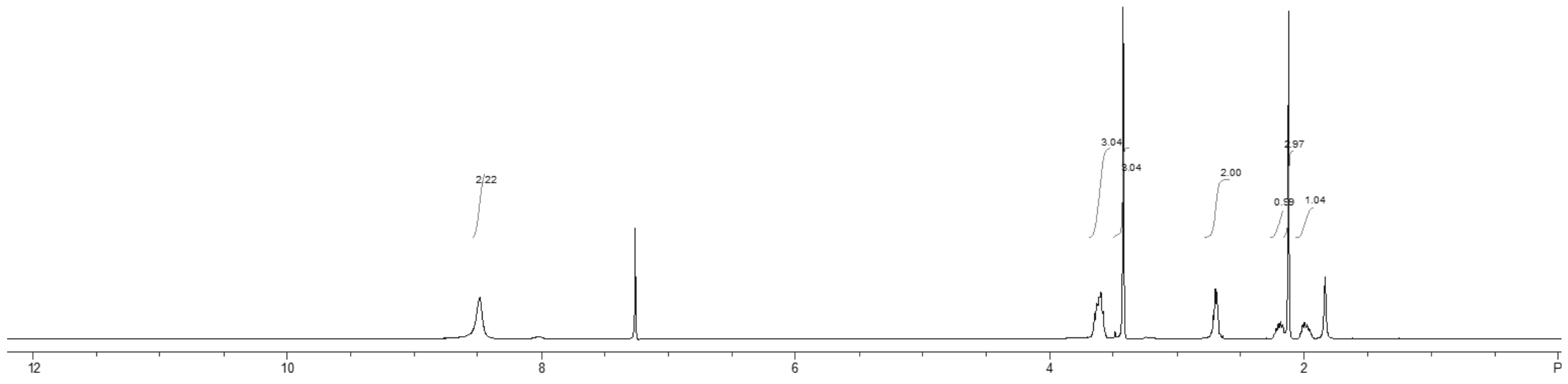

Figure S18. ${ }^{1} \mathrm{H}$ NMR $\left(400 \mathrm{MHz}, \mathrm{CDCl}_{3}\right)$ of 7. 


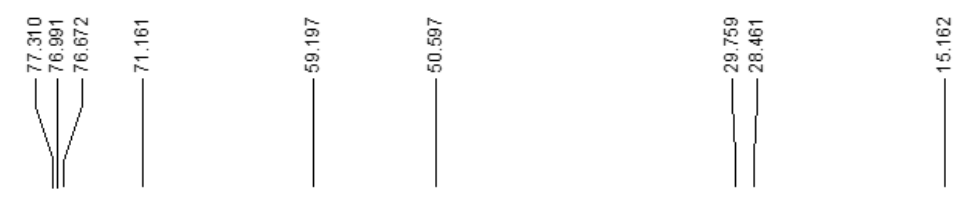

$$
\overbrace{\mathrm{S}^{\prime}}^{\mathrm{NH}_{2} \mathrm{HCl}^{-}}
$$

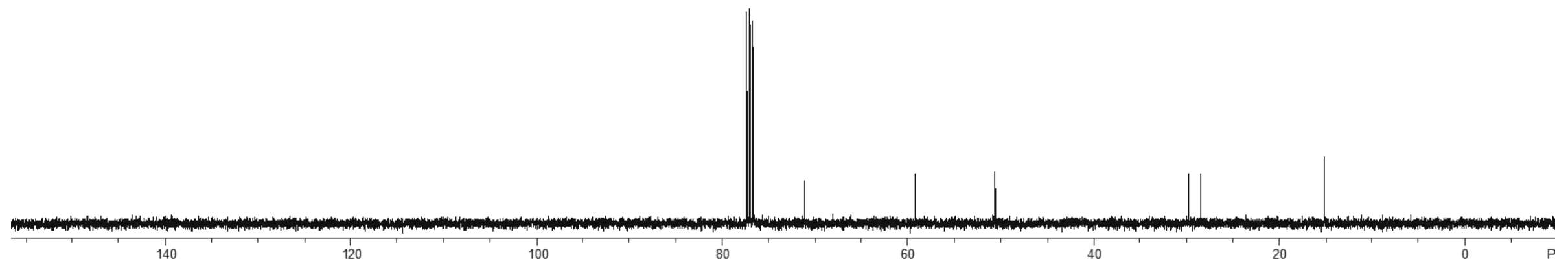

Figure S19. ${ }^{13} \mathrm{C}$ NMR $\left(100 \mathrm{MHz}, \mathrm{CDCl}_{3}\right)$ of 7. 


$$
\overbrace{\mathrm{S}^{\prime}}^{\mathrm{NH}_{2} \mathrm{HCl}}
$$

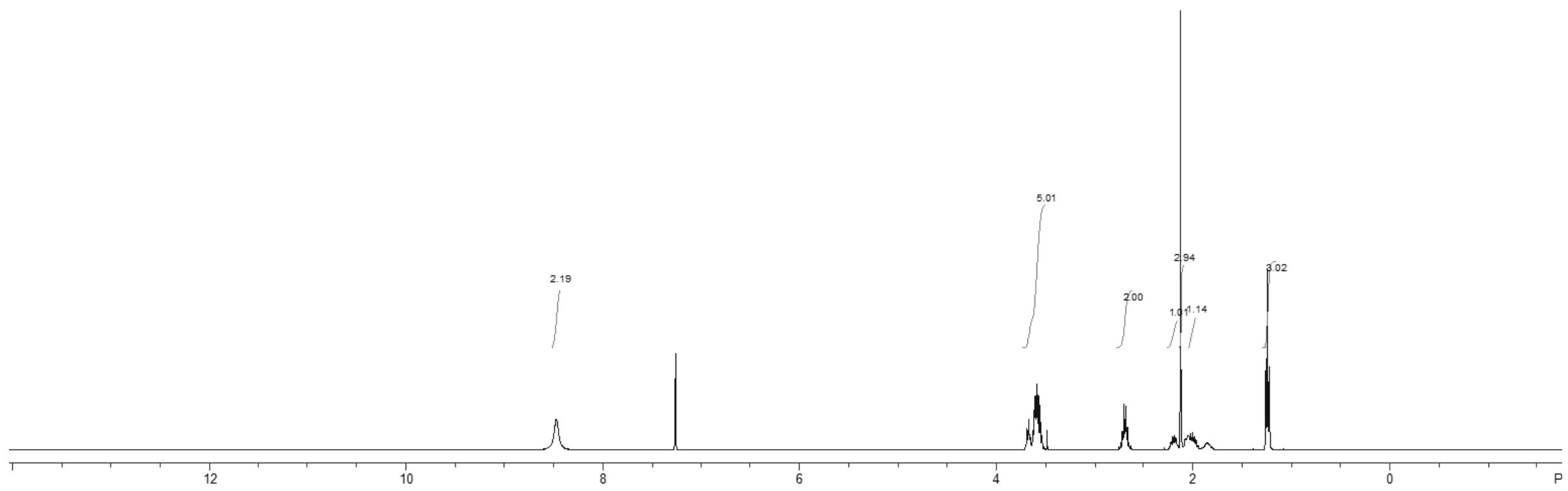

Figure S20. ${ }^{1} \mathrm{H}$ NMR $\left(400 \mathrm{MHz}, \mathrm{CDCl}_{3}\right)$ of 8. 


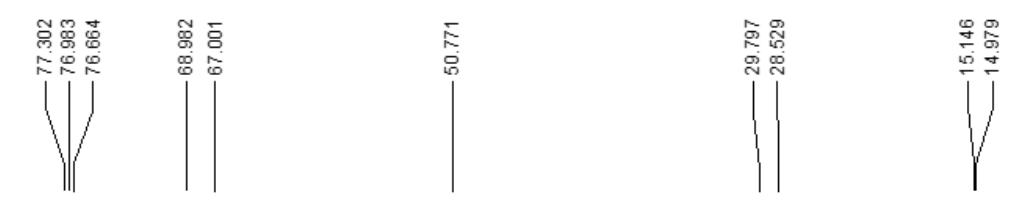

$\sim_{\mathrm{S}^{\prime}}^{\mathrm{NH}_{2} \mathrm{HCl}}$

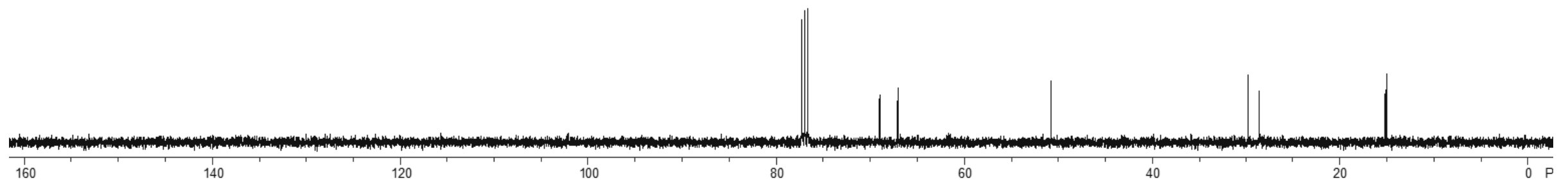

Figure S21. ${ }^{13} \mathrm{C} \mathrm{NMR}\left(100 \mathrm{MHz}, \mathrm{CDCl}_{3}\right)$ of 8. 

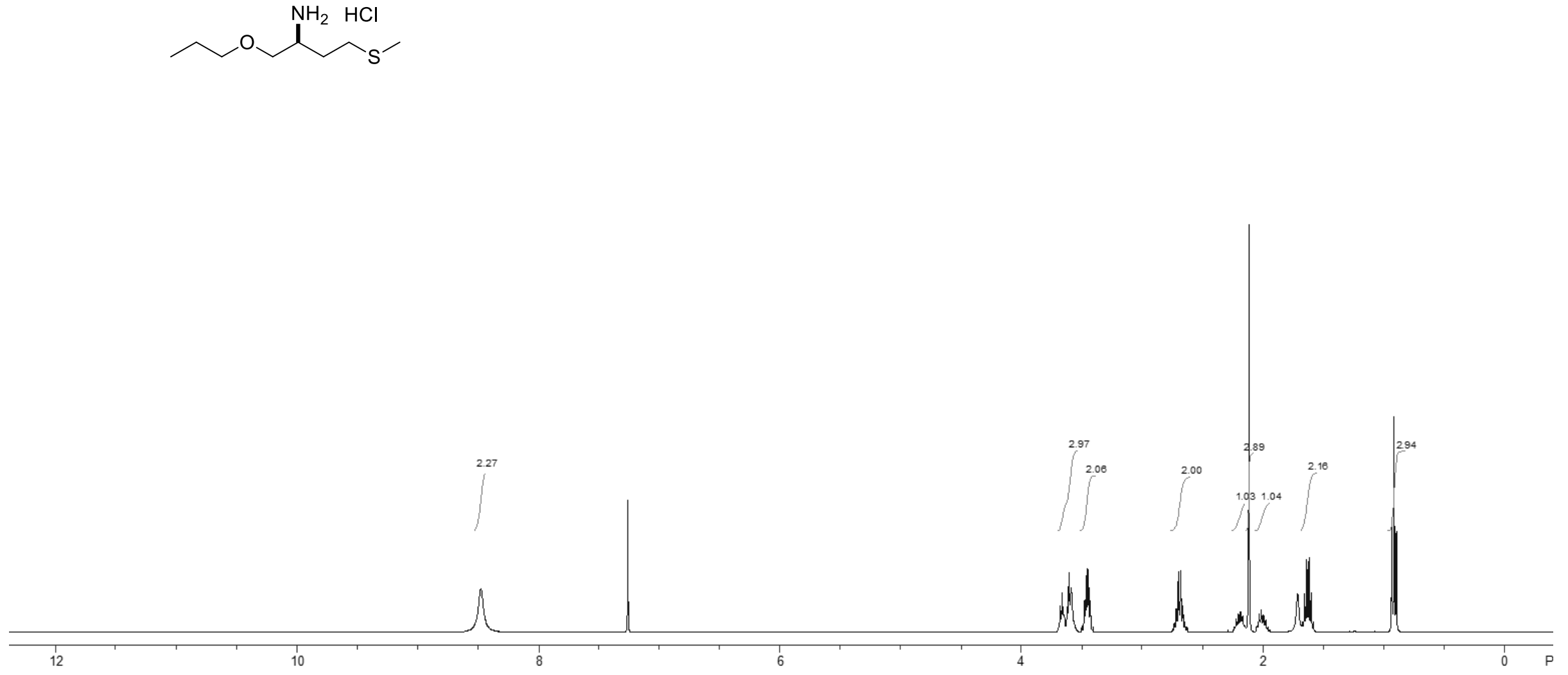

Figure S22. ${ }^{1} \mathrm{H} \mathrm{NMR}\left(400 \mathrm{MHz}, \mathrm{CDCl}_{3}\right)$ of 9. 


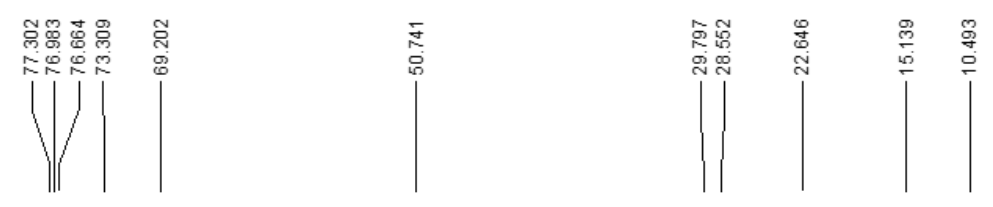

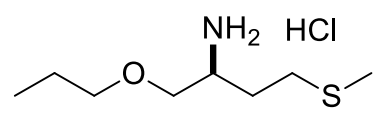

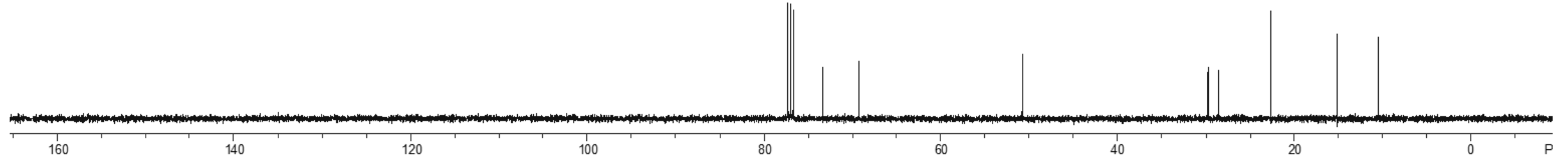

Figure S23. ${ }^{13} \mathrm{C} \mathrm{NMR}\left(100 \mathrm{MHz}, \mathrm{CDCl}_{3}\right)$ of 9. 

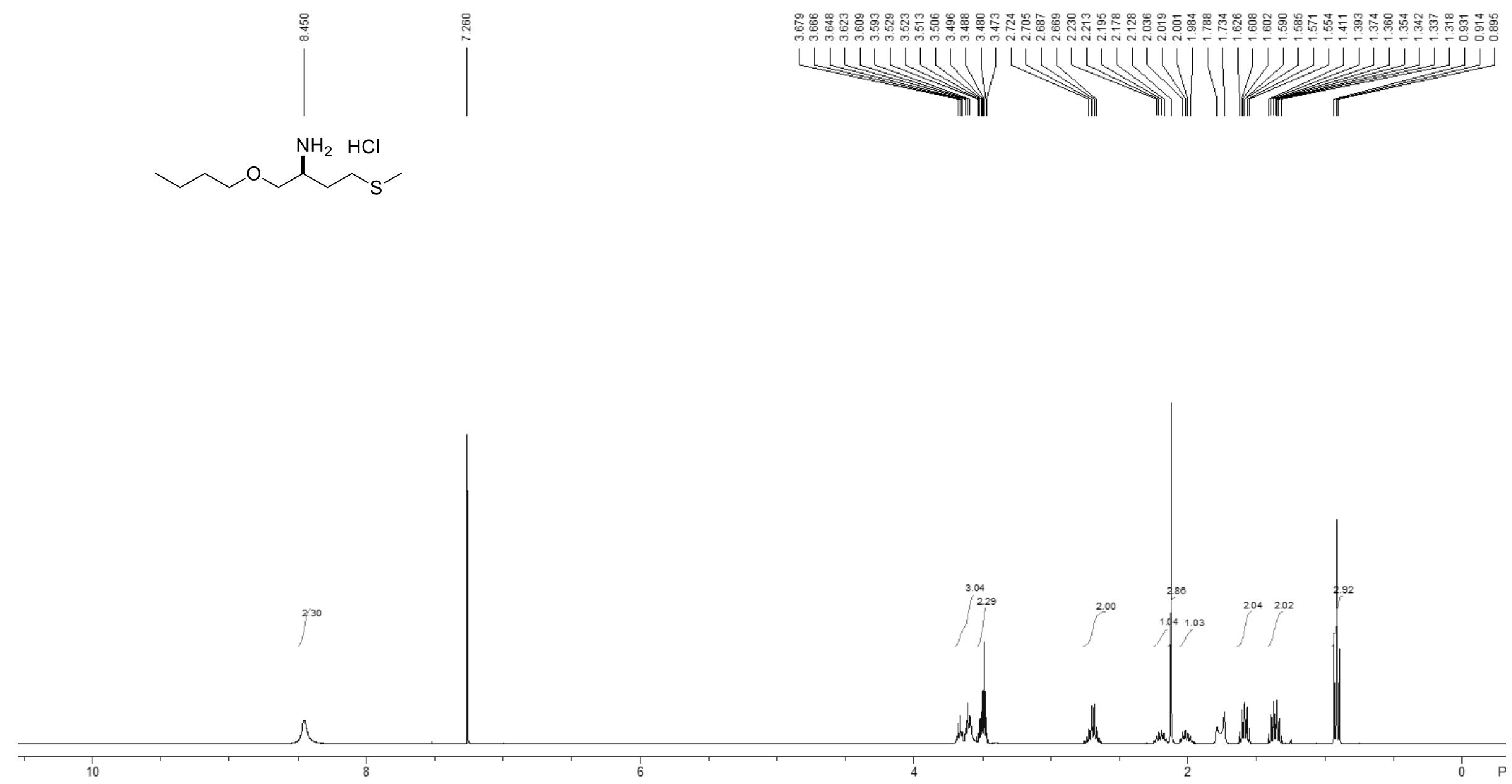

Figure S24. ${ }^{1} \mathrm{H} \mathrm{NMR}\left(400 \mathrm{MHz}, \mathrm{CDCl}_{3}\right)$ of 10. 

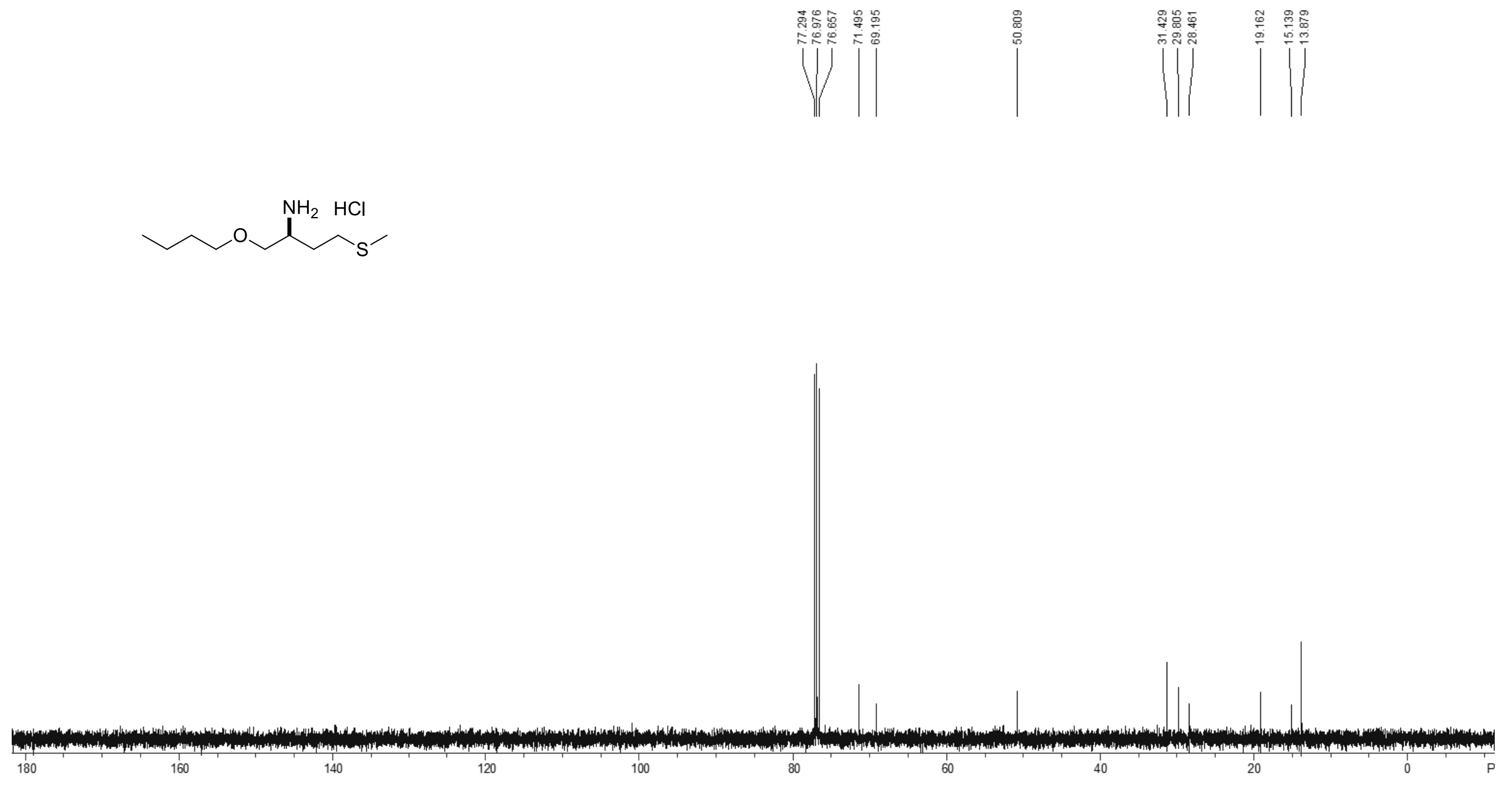

Figure S25. ${ }^{13} \mathrm{C}$ NMR (100 MHz, $\left.\mathrm{CDCl}_{3}\right)$ of 10. 
17-0162 \#24-28 ${ }^{-} \mathrm{RT}^{-}{ }^{-} 0.68-0.80{ }^{-} \mathrm{AV}^{-}{ }^{-}{ }^{-} \mathrm{NL}:{ }^{-} 4.06 \mathrm{E} 8$

T: FTMS + p ESI Full lock ms [125.00-1500.00]

$$
385.1656
$$

$\mathrm{C}_{15} \mathrm{H}_{25} \mathrm{O}_{4} \mathrm{~N}_{6} \mathrm{~S}=385.1653$

$$
\text { 100 } \quad 0.8252 \mathrm{ppm}
$$

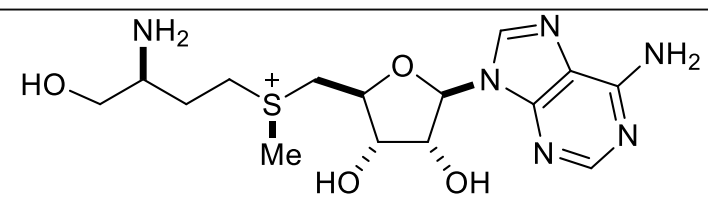

AdoMetol

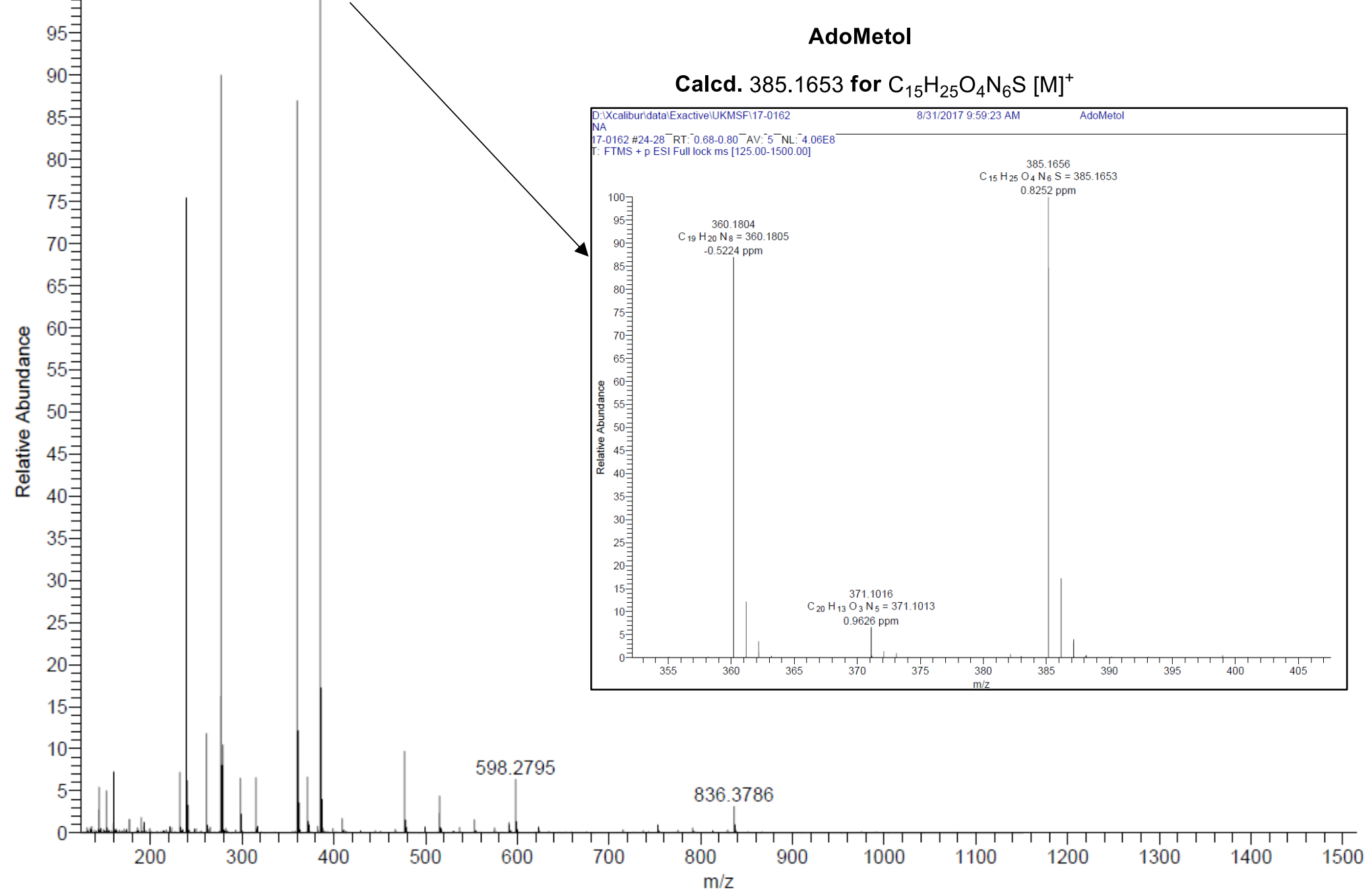

Figure S26. HRMS of AdoMetol. 


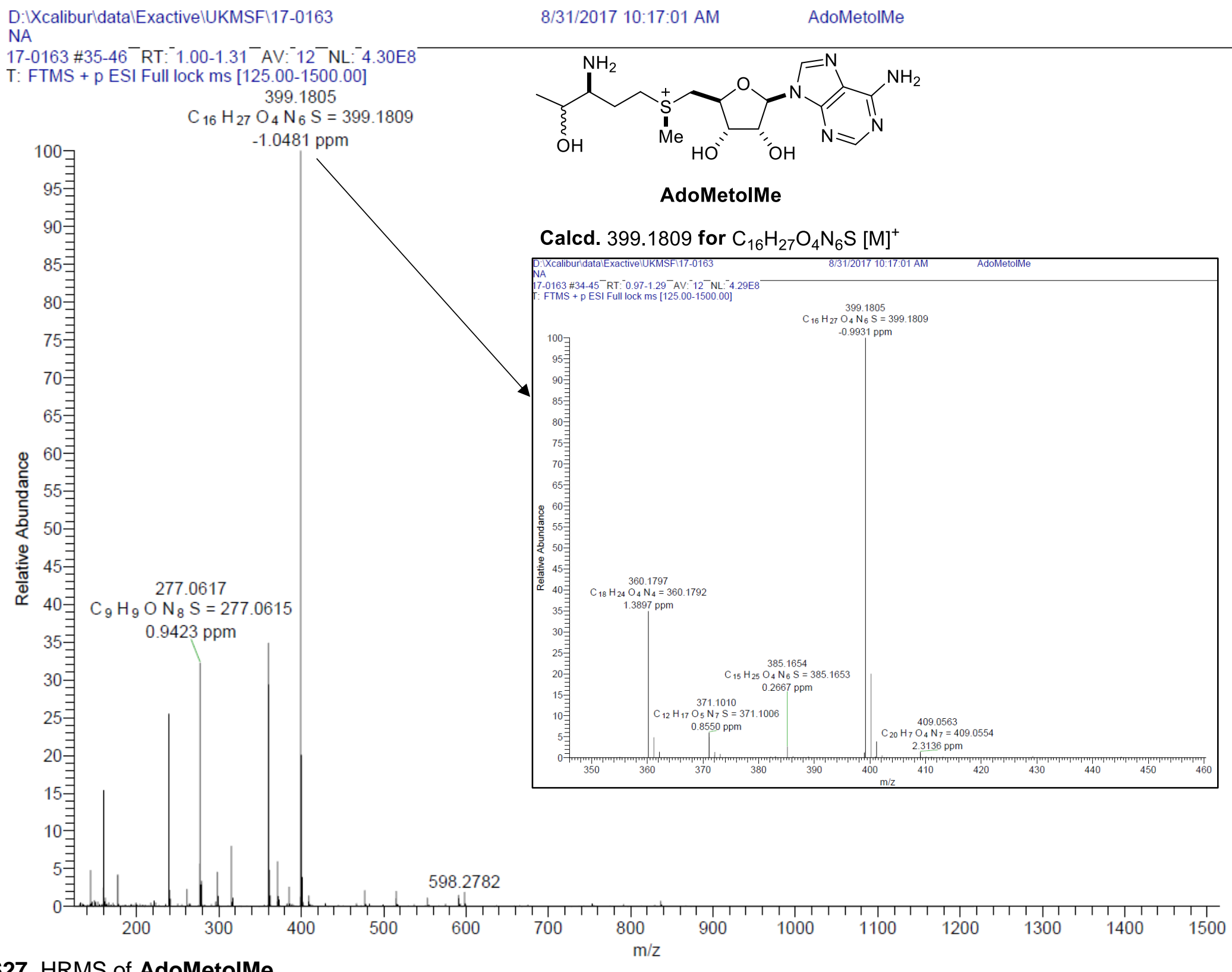

Figure S27. HRMS of AdoMetolMe. 